\title{
Inés Salzillo (1717-1775): una mujer en un taller de escultura del Barroco
}

\author{
Concepción Peña-Velasco \\ Universidad de Murcia \\ velasco@um.es
}

RESUMEN: Testimonios tempranos sobre Inés Salzillo (1717-1775), la menor de las hermanas del escultor Francisco Salzillo (1707-1783), confirman que trabajó en el taller junto a José Salzillo (1710-1744) y Patricio Salzillo (1722-1800), perfilando su cometido hasta su matrimonio en 1748. Resaltan que dibujaba, modelaba, proporcionaba policromía a las imágenes y que Francisco tomó sus rasgos para imágenes devocionales. Se reflexiona sobre su historia de vida y quehacer en la cadena de producción que estableció Francisco Salzillo tras la muerte de su padre, el napolitano Nicolás Salzillo (1672-1727). Inés Salzillo colaboró en años decisivos para dar un nuevo rumbo al obrador y asentar su prestigio.

PALABRAS CLAVE: Inés Salzillo; Escultura barroca española; Historia de vida; Mujeres artistas.

\section{Inés Salzillo (1717-1775): a Woman in a Baroque Sculpture Atelier}

ABSTRACT: Early records on Inés Salzillo (1717-1775), youngest sister of Francisco Salzillo, confirm that she worked in the sculptor's atelier alongside José Salzillo (1710-1744) and Patricio Salzillo (1722-1800) until she married in 1748. She drew, made clay figures, applied the paint finish to sculptures and provided the model that her brother Francisco used in several devotional figures. We reflect on her life and work in the chain of production that Francisco Salzillo established after the death of his father, the Neopolitan sculptor Nicolás Salzillo (1672-1727). Inés Salzillo collaborated during the crucial years that paved the future of the atelier and established its reputation.

KEYWORDS: Inés Salzillo; Spanish Baroque Sculpture; Life Story; Women Artists.

Testimonios sobre Inés Salzillo: «juntaba a las habilidades propias de su sexo no sólo las de dorar, dibujar y modelar, sino también encarnar las estatuas» ${ }^{1}$

En el año 2017 se cumplió el tercer centenario del nacimiento de Inés Salzillo (1717-1775), hija del escultor napolitano Nicolás Salzillo (1672-1727) y de Isabel Alcaraz (1679-1745). Era la menor de las cuatro hermanas del famoso imaginero Francisco Salzillo (1707-1783). Vinculada al taller artístico que dejó su padre, su labor ha pasado en gran medida inadvertida, como también ha acontecido con José Salzillo (1710-1744) y Patricio Salzillo (1722-1800), con diferente grado de protagonismo en el obrador. Sin embargo, desde el siglo XVIII existen testimonios sobre su formación y colaboración junto a Francisco Salzillo y la escueta mención a esta presencia femenina suele ser una constante en las publicaciones sobre el escultor, pese a las dificultades para averiguar las obras concretas en las que trabajó. En este estudio, se ha buscado información sobre ella en diversas fuentes primarias y secundarias con el fin de perfilar su historia de vida, conjeturar sobre las relaciones familiares y reflexionar sobre su cometido y lo que pudo significar su participación activa en el taller durante más de una década; en concreto desde comienzos de los años treinta hasta diciembre de 1748 en que contrajo matrimonio [1] y [2]. Fueron años productivos y de consolidación de la reputación de Francisco Salzillo y la labor silenciosa de sus hermanos debió contribuir al reconocimiento.

Cómo citar este artículo: PEÑA-VELASCO, Concepción, «Inés Salzillo (1717-1775): una mujer en un taller de escultura del Barroco», Boletín de Arte-UMA, n. 39, Departamento de Historia del Arte, Universidad de Málaga, 2018, pp. 49-72, ISSN: 0211-8483, DOI: http://dx.doi.org/10.24310/BoLArte.2018.v0i39.4547 


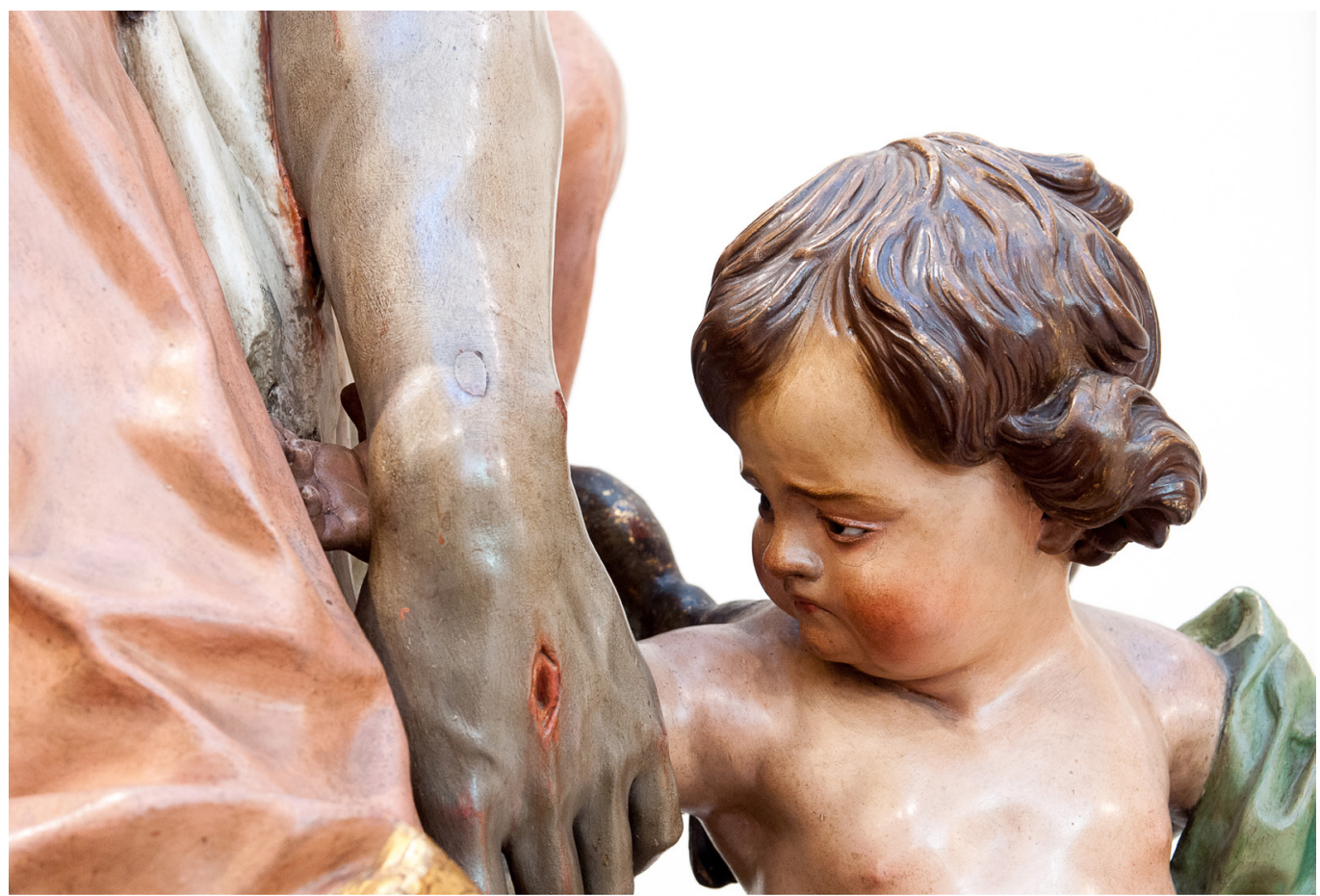

1. Francisco Salzillo, Las Angustias (detalle), 1739, Parroquia de San Bartolomé de Murcia (Fotografía: M. Saura)

Lo que se sabe del quehacer de Inés Salzillo es a través de las palabras. En concreto por los documentos referidos a ella o a familiares. Hablan de su origen, ambiente cultural y social en el que se movió, afectos, trabajo y vida en la casa paterna y, después, junto a su marido e hijos. También por lo que se ha escrito sobre ella y por lo que la oralidad ha perpetuado. La glosa más repetida resalta su diligencia en el acabado cromático de las imágenes. Se completa con las referencias indicando que dibujaba y que fue modelo para los rostros de ciertas imágenes religiosas efectuadas por Francisco Salzillo. Sobre los aspectos de la policromía, se detallaba, además, que diseñaba los motivos para poner en las telas que en la escultura se fingían. Breve pero interesante es el comentario vertido en el manuscrito del matemático murciano Luis Santiago Bado (1751-1833). Del mismo modo y, aunque no citaba su nombre, algo añadía el académico y traductor de importantes tratados artísticos Diego Antonio Rejón de Silva (c. 1754-1796), al hablar genéricamente de los hermanos de Francisco Salzillo. Ambos textos han sido publicados íntegramente en los últimos años (Martínez Ripoll 2006; Martínez Cerezo, 2014 y 2015; García López, 2015).
La más completa descripción de la delimitación de tareas en el obraje la expresaba Bado, quien conoció a Francisco Salzillo, coincidió con él como profesor en Escuela Patriótica de Dibujo de la Real Sociedad Económica de Amigos del País de Murcia y sus progenitores fueron italianos, en concreto de Osiglia en el Marquesado de Finale. Afirmaba que «la familia de Salcillo fue bien mirada del numen en cuya mano ponía el dominio de las Artes» y que, además de Francisco, Inés, José y Patricio «las cultivaron dignamente» (Martínez Ripoll, 2006: 5). Resaltaba que Inés sabía dibujar, modelar y dominaba las técnicas del encarnado y dorado. Es decir, valoraba tareas que requerían conocimientos, destreza y paciencia, matizando que se sumaban a las que le correspondían como mujer. Es significativo que de Inés, José y Patricio destacara lo siguiente:

[...] la primera juntaba a las habilidades propias de su sexo no sólo las de dorar, dibujar y modelar, sino también encarnar las estatuas que ejecutaba su hermano don Francisco. El segundo, escultor de profesión, trabajaba al lado de su hermano con mucha inteligencia, entretenimiento y gusto parti- 
cular en concluir. El tercero, que hoy vive, presbítero y capellán del Convento de Religiosas Capuchinas de esta capital, desempeñó, ínterin que vivió nuestro Salcillo, la encarnación de todas las imágenes y estofado de sus vestidos con la inteligencia y acierto que manifiestan sus obras (en Martínez Ripoll, 2006: 41).

Rejón de Silva sostenía que Francisco Salzillo fue llamado a Madrid a colaborar en el Palacio Real por Baltasar de Elgueta, intendente de tales obras y cuyo hermano -Joséera un diletante con conocimientos y sensibilidad destinado en el Tribunal de la Inquisición de Murcia. Rejón de Silva sostenía que no quiso separarse «de la vista y cuidado de su amada madre y hermanos menores, a quienes asistió como padre hasta que tomaron estado» (Martínez Cerezo, 2014: 63 y 2015: 59; García López, 2015: 119). Insistía, pues, en el deber de atención que el escultor asumió con los suyos y que procuró a Inés y a Patricio, aunque no los mencionase expresamente.

Los testimonios del siglo XVIII de Bado y Rejón de Silva reflejan lo que la gente consideraba sobre una persona estelar como había sido Francisco Salzillo, cuya memoria permanecía viva tras su muerte. En este sentido, es incuestionable que Inés Salzillo trabajó junto a él. Bado y Rejón de Silva nacieron en los años cincuenta del Setecientos y, en consecuencia, sus relatos son muy fiables. Bado es probable que la tratase, pues sus viviendas estaban cercanas y sus círculos de amistades coincidían en una ciudad pequeña (Botías, 2001: 38-53). Por otro lado, se formó como tallista y así figura en los padrones de 1776, momento en que todavía no había enviudado y accedido al estado eclesiástico. En el caso de Diego Antonio Rejón de Silva, no consta que la hubiera conocido y, de hecho, ni la citaba. No obstante y aunque los datos fueran indirectos, la información pudo recabarla o ratificarla con Patricio Salzillo o con personas próximas. Además, se constata la existencia de redes que vinculaban a las familias con anterioridad. Su abuelo Francisco Rejón designó en 1733 como curador ad litem de su hijo Diego Ventura Rejón, también escritor, a Francisco García Comendador I, que años después sería el suegro de Inés (Peña, 1985: 15). Rejón de Silva se trasladó a Murcia en los años noventa, tras la caída en desgracia de su protector el Conde de Floridablanca, y se movió entre élites urbanas -como los Riquelme, Fontes, Elgueta y otros muchos pode-

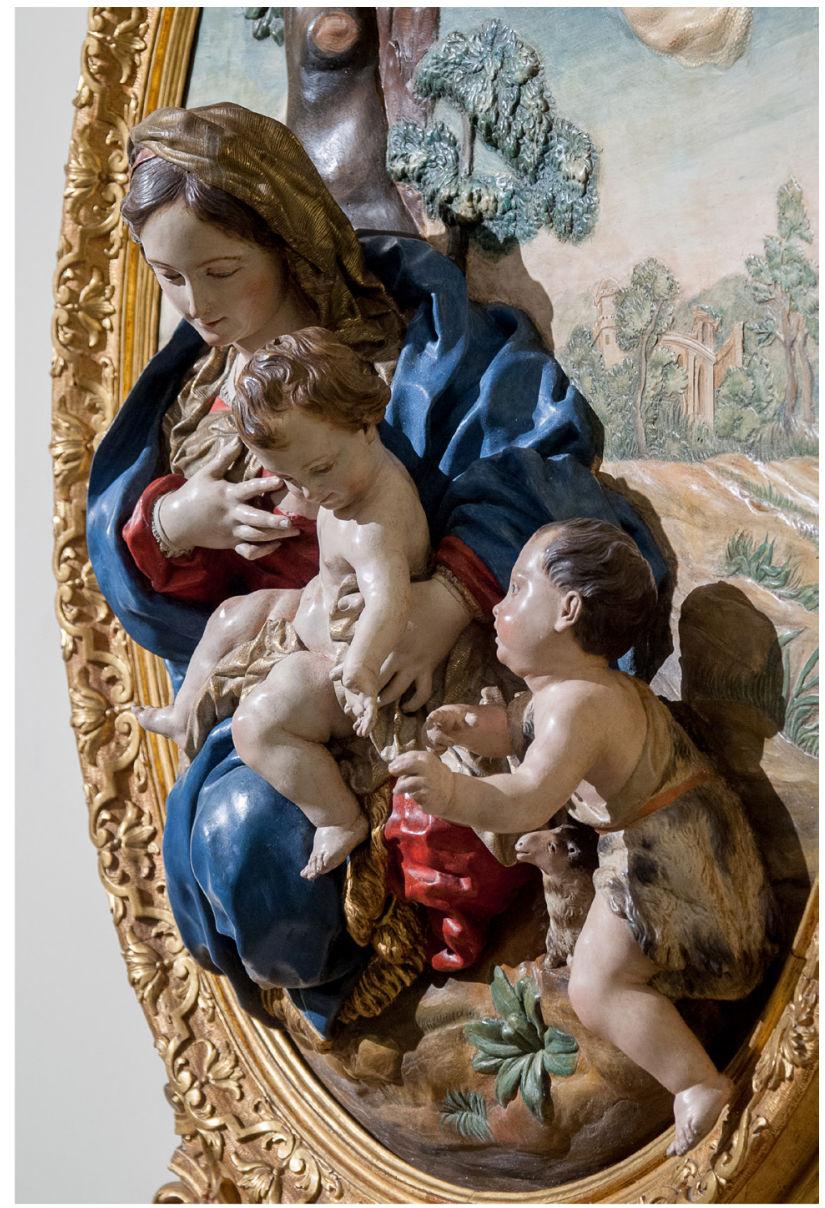

2. Francisco Salzillo, La Virgen de la Leche (detalle), c. 1740, Museo de la Catedral de Murcia (Fotografía: M. Saura)

rosos del clero y del patriciado-, que conocían bien a Francisco Salzillo. No en vano fue síndico personero del común en el concejo de Murcia. En la Real Sociedad Económica de Amigos del País, Rejón de Silva se relacionó con destacados círculos artísticos de la ciudad, donde la huella del escultor permanecía en discípulos y seguidores. Con anterioridad y cuando estaba en la corte, al ilustre académico de la Española y de San Fernando no le faltaron noticias sobre el acontecer cultural en la tierra de sus antepasados.

A partir de 1800, las referencias de Ceán Bermúdez sobre Francisco Salzillo se convirtieron en cita ineludible cuando se escribía sobre el imaginero. Al comentar el trabajo de Patricio estofando y encarnando, añadía que desempeñaba «también esta operación con acierto su hermana D. ${ }^{a}$ 
Inés, que tenía igualmente la habilidad de dibuxar y modelar con gusto é inteligencia» (Ceán, 1800: 26). En el siglo XIX en la prensa y en otras publicaciones subsistió el comentario sobre ella, aunque eclipsado entre las páginas dedicadas a su hermano. Así, en noviembre de 1866 Ramón Chico de Guzmán incluyó en La Paz de Murcia una biografía sobre Francisco Salzillo, añadiendo la acotación sobre la labor artística de Inés. Frente al comentario habitual que insistía en que modelaba, pasó a señalar que se erigiría en modelo y, específicamente, para la Dolorosa: «Sabido es de todos que la Virgen de los Dolores es el fiel retrato de la hermana de Zarzillo, que le ayudaba en sus trabajos, y le sirvió de modelo para su producción» (recogido por Gómez de Maya, 2013: 77). Si bien, en otros textos se hablaba de que fue su hermana Francisca, monja capuchina, quien prestó su semblante a la imagen Santa Clara. Así lo señaló el Conde de la Viñaza (1894: 340; Candel, 1983: 117), sin aludir a Inés, salvo para manifestar que Francisco Salzillo dejó el noviciado dominico al fallecer su padre «para acudir al sostenimiento de su madre y hermanos». Sobre el tema de las féminas que le inspiraron, de manera exagerada el Marqués de Molins -que declaraba estar al tanto de muchos datos por su amistad con Agustín Braco López, biznieto del artista- llegó a valorar en clave de género la repetida afirmación de que copiaba del natural buscando y pagando a pobres para que posasen. El aristócrata y político albacetense le dio un sesgo diferente al comentario habitual y señaló que, si peregrinas y transeúntes le servían a Francisco Salzillo para «samaritanas y magdalenas», "las más honradas damas y las más ariscas zagalas, no rehusaban prestarse horas enteras para representar vírgenes, ángeles y santas», dada la honestidad del artista (en Cánovas del Castillo, 1887: 79). El Marqués de Molins decía estas palabras en la contestación al discurso de entrada del político del Partido Conservador, Antonio Cánovas del Castillo, a la Real Academia de San Fernando el 29 de mayo de 1887 y dedicó un extenso comentario a Francisco Salzillo, que recogió la prensa local murciana. Respecto al tema de la preocupación del imaginero por su entorno familiar, manifestaba: «[...] sacrificándolo todo á su piedad filial y á la educación de sus hermanitos; la mayor parte de los cuales convirtió en discípulos tornando su casa en obrador. D. José le desbastaba la madera y el mármol y aun copiaba sus modelos de barro, a modo de los que en italiano Ilaman scalpelini; el clérigo D. Patricio, con notable instinto pictórico, concluida su carrera eclesiástica, encarnaba y estofaba las estatuas; la misma doña Inés dibujaba y modelaba con gusto e inteligencia» -observaba repitiendo a Ceán- (El Diario de Murcia, 1 de junio 1887; en Cánovas del Castillo, 1887: 78).

A lo largo del siglo XIX Francisco Salzillo se afianzó como figura preeminente y de gran valor en la construcción y reivindicación de la identidad regional. Si por un lado se consolidó popularmente, multiplicándose las leyendas y forjándose tópicos sobre el escultor, también hubo otra corriente de investigación sobre su vida y obra, paralelamente a la realización de un monumento, en un contexto de exaltación y reavivación de la memoria de hombres ilustres, entre ellos los artistas, situados ahora en los «altares de la patria» (Peiró, 2017). Con motivo de los actos organizados en 1883 en el centenario de su muerte, se buscaron y publicaron nuevos documentos, se catalogó su obra y se efectuaron exposiciones localizando piezas en colecciones particulares, al tiempo que la fotografía significó una proyección del escultor más allá de las fronteras locales, por lo que implicaba de visualización de su producción (Marín, 1998: 32-38). En este contexto se situaría Fuentes y Ponte, madrileño con destino en Murcia como Ayudante de Obras Públicas. Sobre Inés Salzillo consideraba que, además de tener a su cargo la parte pictórica, enlenzaba. Escribía que era «muy hábil en dibujar y en componer los motivos de adorno» (Fuentes y Ponte, 1900: 15). Indicaba que se consideraba que Santa Rita, en la parroquia Santa Catalina, evocaba su retrato. Fuentes y Ponte pudo recabar testimonios entre descendientes de Salzillo, pues las fuentes orales tuvieron gran valor para él. En 1913 Baquero dio cuenta de los datos que se habían ido publicando sobre la familia y aportó otros inéditos, reconociendo el mérito de investigaciones como las de Belmonte y su padre, Ramón Baquero (Martínez Cerezo, 2003-2004). Incluyó en su libro la fecha de nacimiento de todos los hermanos Salzillo y mencionó a una primogénita, que murió tempranamente.

Un avance importante en la biografía de Inés Salzillo tuvo lugar merced a las aportaciones documentales de Sánchez Moreno en 1945, quien señaló que, según la tradición, su hermana María también había ayudado en el taller. Consideraba que Inés debió de trabajar entre 1732 y 1748. De María Gómez de Molina, hermana de la abuela materna que falleció sin hijos, localizó su testamento, fechado el 9 
de septiembre de 1732, y el codicilo, que otorgó el 3 de febrero de 1745. En el primero dispuso que Francisca Salzillo recibiera mil reales si tomaba estado y, de lo contrario, que lo repartiera con sus hermanas. En el segundo determinó que ciertas joyas personales pasaran a sus sobrinas, tales como un anillo de oro con tres diamantes a María Salzillo, tres arracadas de oro y perlas a Inés y, a Teresa, otra alhaja de oro (Sánchez Moreno, 1945: 183-186). Las mandas revelan la atención que la tía de los Salzillo tuvo con sus sobrinos nietos, a sabiendas de que Isabel Alcaraz, madre de estos últimos, había quedado huérfana de padre y que su madre, Magdalena Gómez, se había vuelto a casar y tenía más descendencia. Sánchez Moreno documentó que Inés contrajo matrimonio con el procurador Francisco García Comendador II en 1748, que murió en 1775 y que otorgó un poder para pleitos en 1744. Dio a conocer los testamentos de Teresa, María y Patricio Salzillo, ratificando que estos mantuvieron el contacto y afecto con los hijos y nietos de Inés, favoreciéndolos patrimonialmente frente a la única hija que vivía de Francisco Salzillo.

Publicaciones posteriores sobre Francisco Salzillo no olvidaron mencionar a Inés Salzillo (Pardo, 1983: 40; Belda, 2001; Peña y Belda, 2006: 23; Ramallo, 2007: 11). Su nombre ha sido citado en trabajos recientes sobre mujeres en las artes plásticas y vinculadas a la escultura barroca (Aranda, 2007: 35; Muñoz López, 2009: 80; Sánchez López, 2016: 92), así como otras sobre policromía, señalando que firmó en alguna ocasión (Gómez Espinosa et al., 2002: 40). Ruiz (2017) le dio nueva actualidad en la prensa murciana, preguntándose y sugiriendo algunas imágenes marianas y santas a las que pudo dar rostro. Finalmente, los avances en los estudios sobre la historia de las mujeres y de la familia han proporcionado claves para un mejor entendimiento e interpretación de ciertas cuestiones surgidas.

\section{Inés Salzillo, historia de vida}

Inés Salzillo, la pequeña de las hermanas y la penúltima de los hijos de Nicolás Salzillo e Isabel Alcaraz, nació en Murcia en abril de 1717 y fue bautizada en la parroquia de Santa Catalina. Sus progenitores no eran padres jóvenes, pues su madre cumplió ese año 38 y su esposo 45 y estaban próximos a los 18 de matrimonio. Entre los bienes de Nicolás
Salzillo, había un cuadro sin marco de Santa Inés valorado en 30 reales, lo que reflejaría la devoción que le profesaban a la santa. Habían transcurrido diez desde el nacimiento de Francisco Salzillo y siete de José. Cinco después llegó Patricio. Los cuatro formaron parte del taller familiar y mantuvieron siempre un fuerte vínculo afectivo, que también mostraron con sus hermanas, nacidas en 1704, 1712 y 1713 (Baquero, 1913: 210), con los problemas propios de la vida y del trabajo en común. Teresa y María quedaron solteras y Francisca de Paula profesó en capuchinas. Hasta los esponsales de Francisco e Inés Salzillo, apenas tuvieron parientes directos en la ciudad, salvo por parte de su abuela materna. Su padre, Nicolás Salzillo, era napolitano y llegó solo. Su madre, Isabel Alcaraz, era murciana y única descendiente de Juan Alcaraz -natural de Herencia- y de Magdalena Gómez -con oriundez murciana pero sus padres provenían del lugar de Isso, en Hellín-. Magdalena contrajo segundas nupcias con un comerciante genovés llamado Jerónimo Musso -Muzio-, cuando Isabel Alcaraz contaba algo más de cinco meses $^{2}$. Ambos cónyuges fallecieron en 1717, año en que Inés vino al mundo. Magdalena Gómez había llevado a su segundo enlace los bienes que quedaron del primer marido, por lo que surgieron dudas en el reparto de la herencia. Los inconvenientes planteados por la división del patrimonio entre los «hermanos uterinos» se prolongaron a la generación siguiente. Sin embargo, los Salzillo recibieron atención por parte de María Gómez, hermana de su abuela Magdalena, que no tuvo hijos. María Gómez perdonó a Isabel Alcaraz -ya viuda- 400 reales que le adeudaba Nicolás Salzillo. Además benefició a Francisca de Paula Salzillo y a sus hermanas (Sánchez Moreno, 1945, 184-185; Peña y Belda, 2006: 22). Francisco Salzillo figuraba por entonces -1717- como porcionista en el Colegio de la Anunciata de la Compañía de Jesús de Murcia (Ibáñez, 1935: 50). Nicolás Salzillo había concluido poco antes la imagen de San Judas [3] para la parroquia de San Miguel y José Caro Utiel, hijo de un tallista y escultor de Orihuela, había terminado su aprendizaje con él (Sánchez-Rojas, 1977-1978: 269).

En 1727, Inés Salzillo perdió a su padre siendo una niña. Había cumplido una década y Francisco, que le doblaba en edad, asumió la dirección de un taller que había de sustentar a una amplia prole. Inés no pudo aprender los rudimentos del oficio con Nicolás Salzillo, pero, entre los recuerdos de su infancia, permanecerían retazos de lo que 


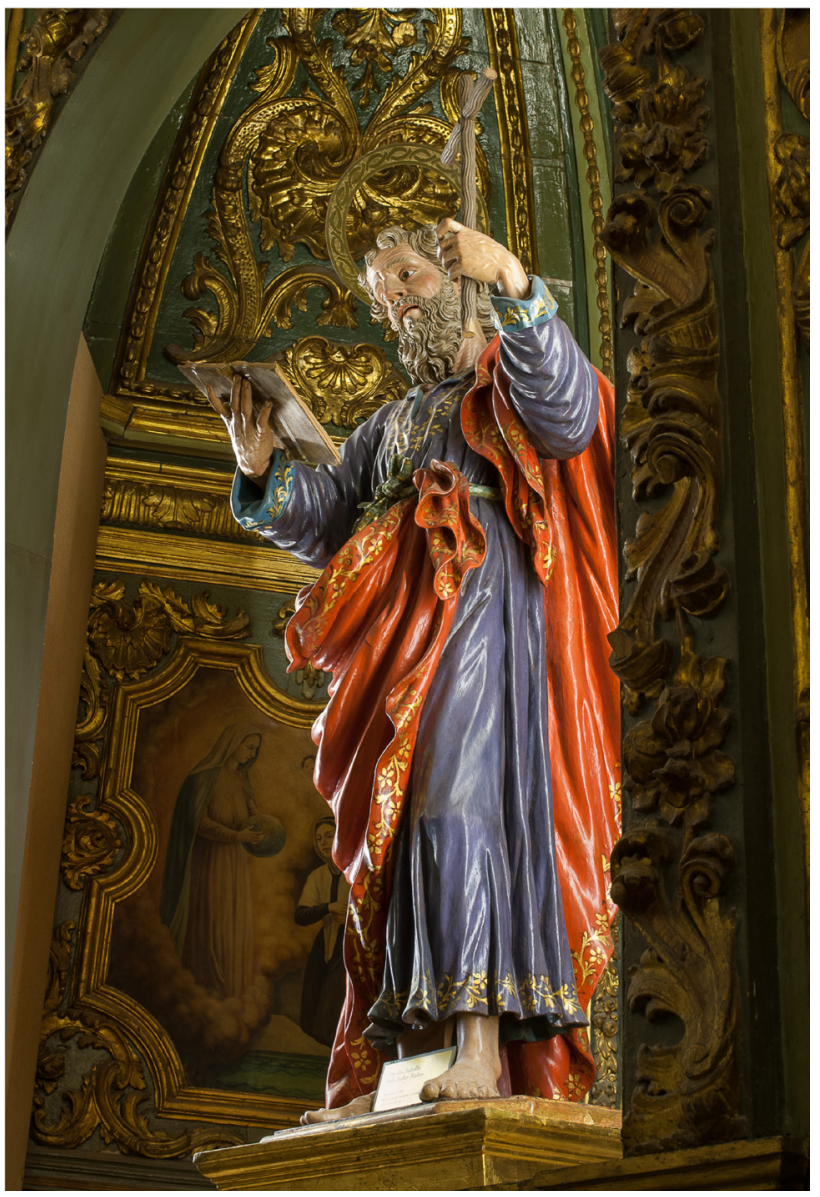

3. Nicolás Salzillo, San Judas Tadeo, c. 1715, Parroquia de San Miguel de Murcia (Fotografía: M. Saura)

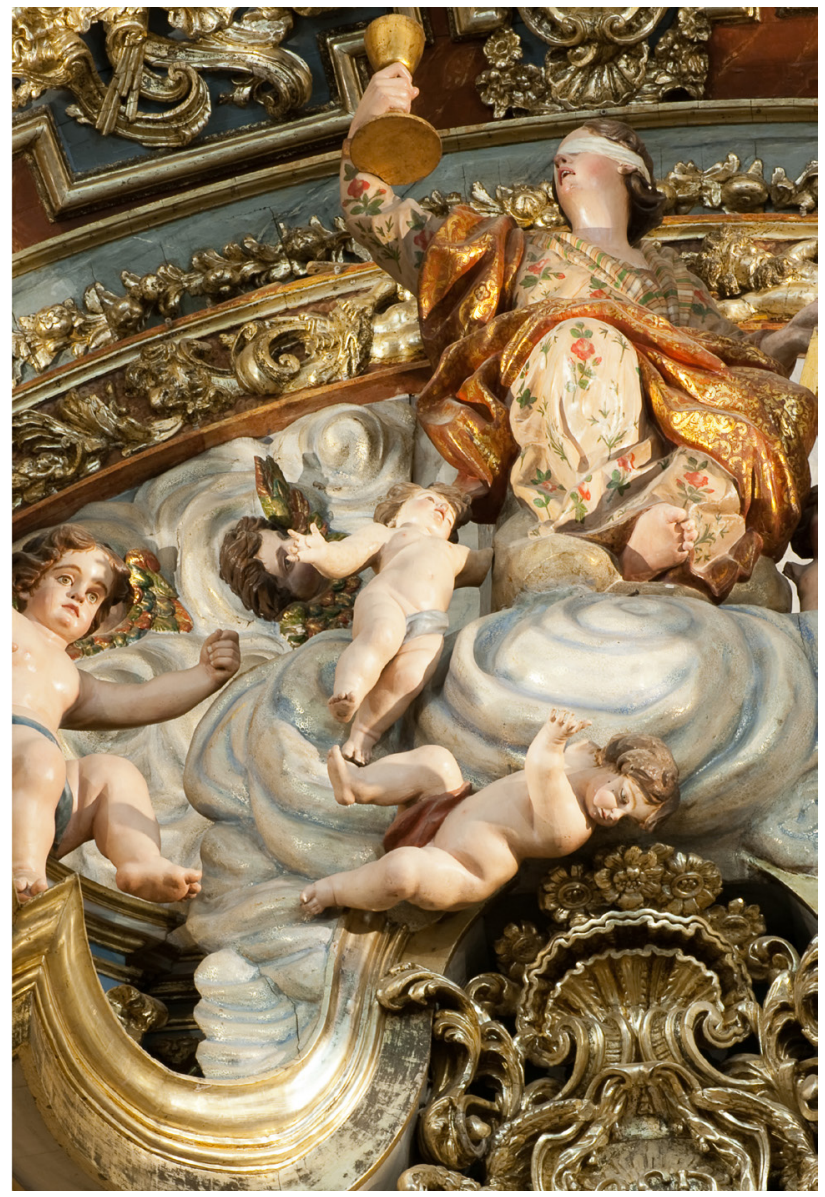

4. Francisco Salzillo, La Fe, c. 1731-1737, Retablo mayor de la Parroquia de San Miguel de Murcia (Fotografía: M. Saura)

Inés era procurador. Por ende, su cónyuge e hijos acapararían su tiempo, como correspondía a su condición de casada y a la exigencia de permanecer en el hogar, según dictaban las convenciones sociales y religiosas. Por otro lado, el quehacer de imaginero incumbía a los hombres, por la dureza del trabajo y del material que requería fuerza, poco acorde a la imagen de fragilidad asociada a la condición femenina que, en cambio, sí era más adecuada al acabado polícromo de la pieza escultórica, que demandaba delicadeza y cuidado en los detalles (Sánchez López, 2016). Por otro lado, tampoco las mujeres podían adiestrarse en el dibujo de academia, copiando del natural, por lo que era más complicado que sus conocimientos fueran completos. Luisa Roldán, escultora que trabajó tanto la madera como el barro, fue una 


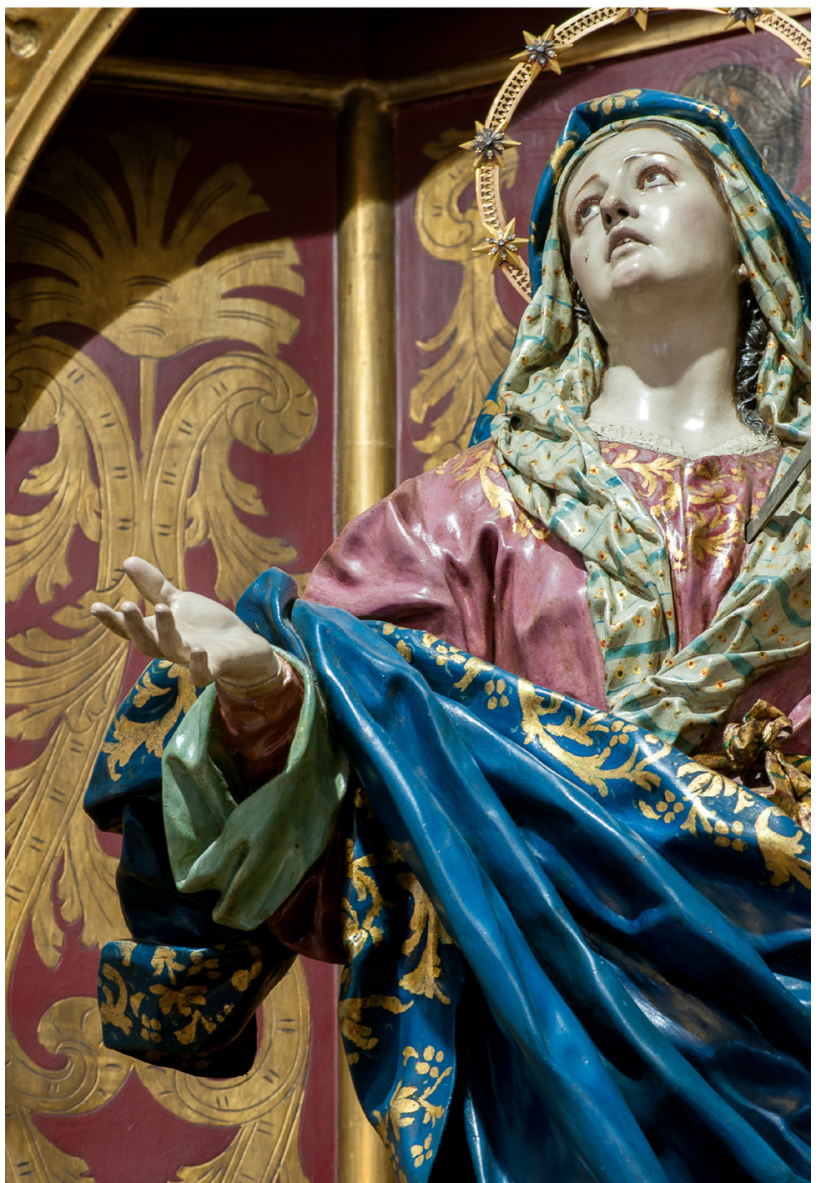

5. Francisco Salzillo, Dolorosa (detalle), 1742, Iglesia de Santa Catalina de Murcia (Fotografía: M. Saura)

excepción por el reconocimiento y los nombramientos que llegó a alcanzar en vida en la corte, ayudada por su marido dorador. También estaban sus hermanas. La mayor, María Roldán, casó con el escultor Matías de Brunenque y recientemente se le han podido asignar tres imágenes del retablo mayor de la parroquia de Olivares (Comas, 2016). Francisca Roldán, esposa y madre respectivamente de los escultores José Felipe Duque Cornejo y Pedro Duque Cornejo, daba color y estofaba (Sánchez López, 2016), como sucedía con Inés Salzillo. Además, Andrea y Claudia de Mena, hijas de Pedro de Mena, aprendieron la profesión que era tradición en la familia desde generaciones atrás y llegaron a realizar obras para su convento malagueño, firmando algunas piezas (Sánchez López, 2016). En el siglo XVIII se documenta

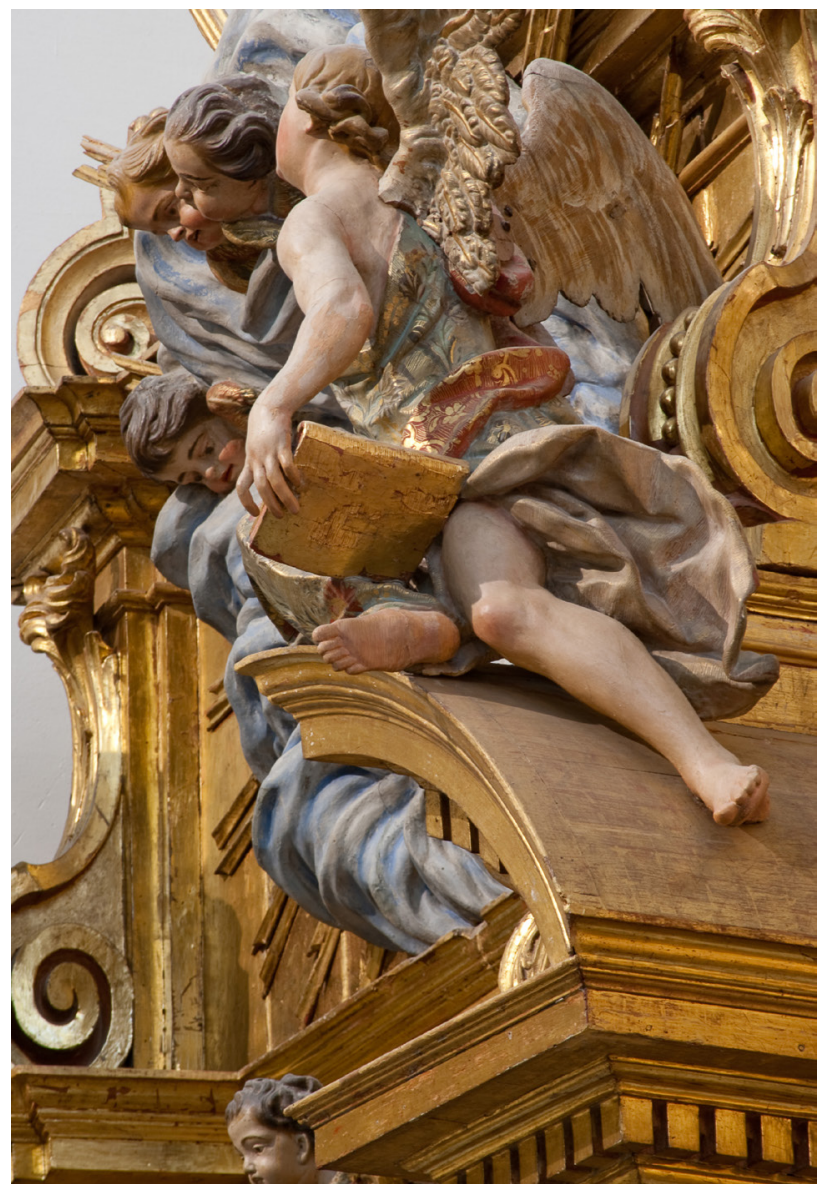

6. Francisco Salzillo, Ángel, c. 1745, Retablo del colateral del evangelio, Parroquia de San Miguel de Murcia (Fotografía: M. Saura)

el trabajo de las hermanas María Feliz y Luciana de Cueto, quienes, tras la muerte de su padre Jorge de Cueto, efectuaron imágenes de devoción (Jiménez Barranco, 2000; Sánchez López, 2016). Pero hubo otras muchas mujeres que colaboraron con diferente grado de responsabilidad en el taller, que era distinto a la mera afición o a una educación humanística que incluyera la enseñanza del dibujo y el desarrollo de habilidades artísticas en ciertas clases sociales, que no a la práctica privada de la pintura (Aranda, 2007: 41-44).

En la nómina de mujeres artistas, las pintoras prevalecen. Sin embargo, el número de escultoras barrocas se incrementará en el futuro cuando se tenga mayor conocimiento de las obras y de los documentos, así como de la vida doméstica (Aranda, 2007). Habrá nombres que nun- 
ca aparecerán, pese a que ellas hubieran contribuido con mayor o menor dedicación al quehacer artístico familiar. Es razonable que ayudaran en los talleres de padres, hermanos, maridos e, incluso, hijos. Hogar y taller solían estar en el mismo inmueble. En consecuencia, ambos formaban parte de su cotidianeidad y, aunque ellas significasen un fulcro constante en el sistema familiar, su labor permanecerá en muchas ocasiones en el anonimato, salvo algún caso de viudas manteniendo el obrador por el período establecido legalmente y según tuvieran o no hijos menores. Esta circunstancia no siempre implicaba que poseían conocimientos de la profesión, pues las viudas permanecían con el taller para liquidar el género o continuaban con la participación de un oficial que se examinaría posteriormente (García Abellán, 1976: 139). Era una prerrogativa que contenían numerosas ordenanzas de artesanos, con ciertas restricciones, como perder el derecho si se casaba o si lo hacía con alguien que no fuera del oficio, al menos hasta el decreto de 1790. También había acuerdos consuetudinarios o reglados en otras profesiones. En Murcia y en el caso de la escultura, existían tales costumbres, porque alguna viuda figura en el Catastro del Marqués de la Ensenada (Murcia 1756, 1993: 293-294), que es una fuente esencial para el conocimiento del trabajo de las mujeres en la sociedad preindustrial (Álvarez y Ramos, 2018). Inés Salzillo no alcanzó la maestría como escultora, ni como pintora, según uso y prácticas tenidas entonces en el antiguo Reino de Murcia. Curiosamente, un siglo después descolló Cecilia Sánchez Araciel quien, junto a sus hermanos y guiados por su padre Francisco Sánchez Tapia, intervendría en la «restauración» de los pasos de Salzillo de la Cofradía de Jesús y en otras obras. En Murcia, se documenta el nacimiento en 1726 de Françoise Duparc, que obtuvo celebridad como pintora discípula de Jean-Baptiste van Loo y que murió en Marsella (Gaze (ed.), 2011: 283-284). Era hija del escultor francés Antonio Dupar -Antoine Duparc- y la apadrinó el regidor Gil Antonio de Molina, después Marqués de Beniel. Otras mujeres familiarizadas con los pinceles en el Barroco murciano fueron Magdalena Gilarte y Antonia Vila, sobrina e hija respectivamente de Mateo Gilarte y Senén Vila (Agüera, 1994: 163).

Además de las enseñanzas artísticas, Inés Salzillo recibiría la educación que se otorgaba a las mujeres: primero para ser buena hija y hermana y, después, buena esposa y madre. La familia era profundamente religiosa y las prácticas de piedad eran parte de su vida cotidiana. La firma de Inés en diversos documentos -incluso anteponiendo doña, con lo que implica de rango el tratamiento- revela que sabía leer y escribir [7], no así su madre, ni sus hermanas María y Teresa, pues el testamento de Isabel Alcaraz y otros papeles de archivo ratifican que lo ignoraban. Es posible que María Salzillo aprendiera tardíamente, porque en su declaración de última voluntad exponía que no firmaba por su avanzada edad y tener tembloroso el pulso (AHPM, prot. 2355, 1784, ff. 323r-325v; Sánchez Moreno, 1945: 186). Incluso, señalaba también en 1784 que deseaba que quedara sin efecto un papel en blanco de «su puño y letra» que había refrendado con anterioridad, sin que se concluyera si era «objeto de vale, escritura, recibo u otro documento». Evidenciaba con ello formas de comportamiento arraigadas en las mujeres iletradas o con escasa preparación, que signaban sin conocer el tenor de lo que suscribían, al no saber leer o porque el pliego suscrito se rellenaría con posterioridad. Es evidente que tales referencias son una prueba más de su indefensión y cuanto menos de su debilidad legal, pues no decidían, sino que quedaba al arbitrio de quien por ellas determinara, probablemente en este caso un familiar, ante lo que podía convenirles o no. El grupo escultórico de Santa Ana y la Virgen de Francisco Salzillo ofrece una imagen evocadora de un tipo de instrucción materno filial en la lectura que Inés no recibió, pero que sí pudo dar después a su hija María Josefa. Es posible que sus hermanos Francisco y José la enseñasen a leer y escribir, pues su padre no lo hizo con sus hijas mayores y su madre no sabía. Isabel Alcaraz cuidaría de otros aspectos de la buena crianza y educación, comenzando por el ejemplo que ella podía ofrecer para determinar en sus cuatro hijas una conducta virtuosa y cristiana, honesta, prudente, modesta y que atendiese a las normas de civilidad, al tiempo que las prepararía para afrontar el gobierno doméstico y para proporcionar felicidad a los suyos. Quizá la lectura en voz alta teniendo Inés el libro en sus manos formara parte de las veladas que las féminas compartían en su casa, mientras cosían o charlaban, pues la costura y las labores del hogar formaban parte de su cometido ordinario. No cabe descartar que Inés entendiese el italiano, pues primero escucharía a su padre de niña, a la vez que el napolitano, pero también por los círculos en los que se movió. En octubre de 1734, Francisca de Paula Salzillo entró en el convento de capuchinas y profesó al año siguiente. Los testimonios de la época -en 


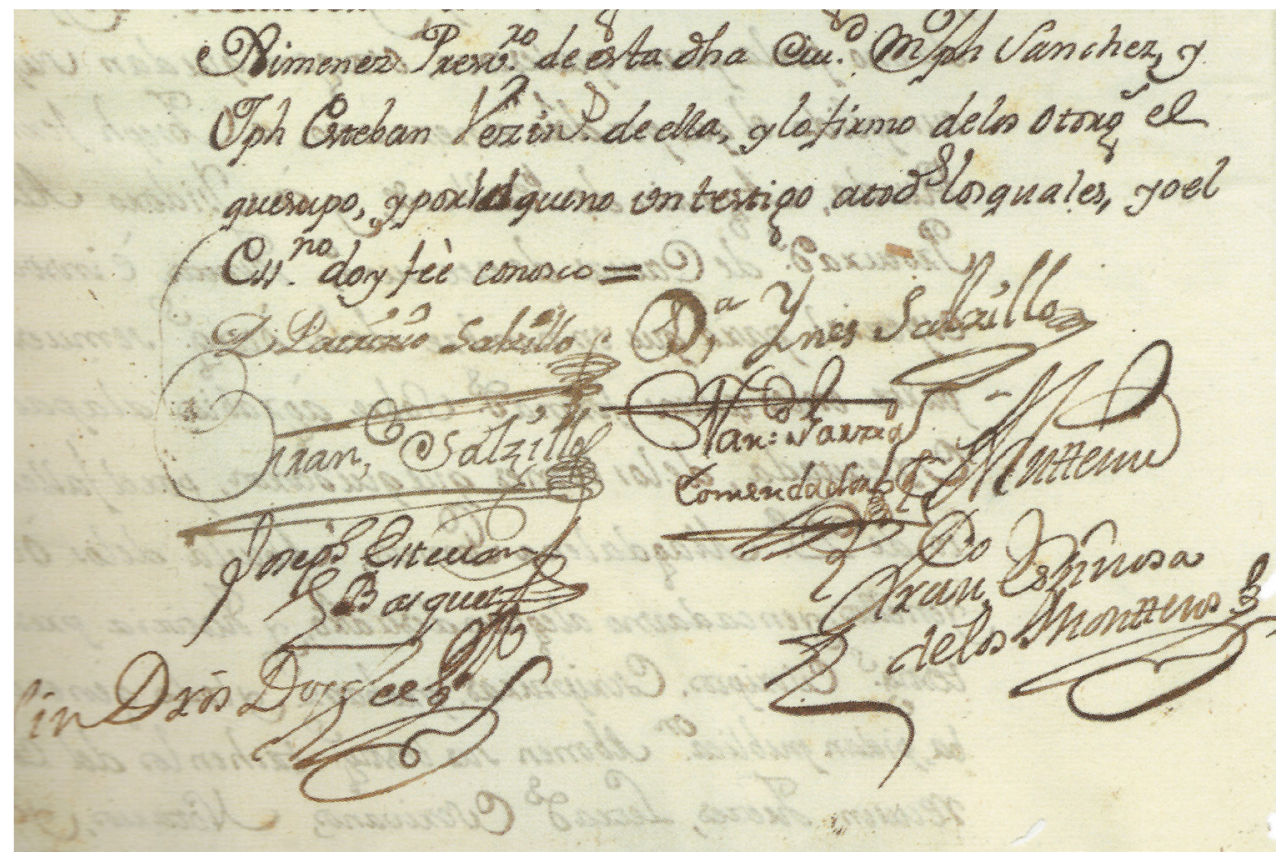

7. Firma de Inés Salzillo, de su marido Francisco García Comendador, de Francisco Salzillo, de Patricio Salzillo y de otros

concreto, los que se escribieron tras su muerte, acontecida en 1759, en el libro de memorias de las religiosas- hablan de ella como persona observante de los votos, señalando que «desempeñó los oficios que llevó por obediencia a satisfacción de la comunidad», que tuvo «mucho quebranto de salud» y que "se esforzaba cuanto podía y más de lo que podía» (recogido por Candel, 1983: 116). Posiblemente en el entorno familiar se cimentó está educación basada en la sumisión, el respeto y el esfuerzo, por lo que cabría suponer que a sus hermanas les inculcaron similares valores. De modo que Inés acataría las decisiones de su hermano Francisco y efectuaría la labor que él determinó que hiciera.

En 1743, los nombres de Francisco y José Salzillo y Jaime Bort, que dirigía la construcción del nuevo imafronte barroco de la catedral (Hernández, 1990), fueron los únicos en Murcia que se consideraron dignos para constar en la relación que se recabó por España de escultores para trabajar en el Palacio Real (Albarrán, 2008: 209). Por entonces, Francisco y José temieron por el futuro del obrador ante la posibilidad de que recayese en ellos el sorteo de milicias para el reemplazo de soldados, pues, aunque consideraban que debían de estar exentos por su profesión, su nombre había sido incluido en las listas. De ahí que junto al escultor Francisco González dieran poder el 13 de noviembre de 1743 a José Pérez, arquitecto y escultor murciano residente en la corte, para conseguir que los borrasen del padrón y se les eximiese de la carga de soldada, petición que casi cuarenta años antes había reclamado su padre alegando similares razones (Sánchez Moreno, 1945: 43; Belda, 1992: 52-55 y 2001: 43-44; Herrero (coord.), 2006: 86-89). Por entonces, Salzillo solicitó al obispo licencia para fundar patronato sobre ciertas posesiones, de modo que su hermano Patricio pudiese ascender al estado sacerdotal. Por decreto de 13 de noviembre de 1743, el obispo Mateo se lo concedió. Se formalizó la escritura el 13 de febrero de 1744, disponiendo que las propiedades recaerían sobre Francisco Salzillo en caso de obtener Patricio renta eclesiástica o de fallecer (Herrero (coord.), 2006: 197-207). Estos y otros acontecimientos sucedidos por entonces debieron determinar en los Salzillo la voluntad de aclarar los aspectos relativos a la propiedad de sus bienes, pues cuando murió su padre Nicolás Salzillo en 1727 se hizo inventario de sus pertenencias pero no reparto entre herederos (Sánchez-Rojas, 1977-1978: 259). Así se desprende de varios documentos, pero esencialmente del 
testamento de Isabel Alcaraz y de la liquidación que se hizo entonces entre ella y Francisco Salzillo. El primero se fecha el 5 de enero de 1744 y es muy interesante porque compendia la situación económica y laboral vivida tras la orfandad paterna (AHPM, prot. 3961, ff.1r-3v; Sánchez Moreno, 1945: 185). Cabe resaltar que esta escritura fue suscrita por sus descendientes, que estuvieron presentes, salvo, lógicamente, la religiosa capuchina, de quien se señalaba que, para su profesión, se gastaron más de 8.000 reales y que los dio Francisco Salzillo de lo adquirido «con su industria y trabajo de escultura». La matriarca de los Salzillo afirmaba que, no teniendo con qué reintegrárselo a su primogénito, le dio una tahúlla, que era la que le había correspondido a Francisca de Paula de la partición de su abuela Magdalena Gómez. Declaraba que Francisco primero pagó las deudas de su padre, luego amplió y arregló la casa que habitaban según gastos de mejora apreciados por el reputado alarife Pedro Pagán y costeó los censos. Además les proporcionó a ella y a sus hermanos cuanto necesitaron "para su manutención y mayor dezencia». Sus hijos lo atestiguaron y Francisco lo aceptó y agradeció. Isabel insistía en que todo lo había satisfecho este con lo "ganado de su trabajo», añadiendo: «sin que los demás de sus hermanos aian gastado ni suplido maravedís algunos por no allarse con empleo ni otro medio para adquirir» (AHPM, prot. 3961, 1744, f. 3v; Peña y Belda, 2006: 20).

Finalizando enero de 1744 se verificó liquidación de la herencia de Nicolás Salzillo entre su viuda y su hijo Francisco (AHPM, prot. 3961, ff. 15 y ss (2. a num.); Sánchez-Rojas 1977-1978). El documento viene precedido por la copia de los testamentos de los cónyuges fechados en 1708 y 1744 , del inventario de bienes verificado tras el fallecimiento del primero y de una declaración conjunta de Isabel Alcaraz y sus hijos en enero de 1744. En esta última, la viuda del escultor napolitano manifestaba que había consumido la mayor parte de su dote -dote considerable de 12.522 reales y 5.500 en arras y donación propter nuptias (AHPM, prot. 3739, 18 julio 1700, ff. 371r-374v; Sánchez Moreno, 1945: 32; Peña y Belda, 2006: 18-19)- y que no había «sido toda respecto de haver suplido el dicho Don Francisco mi hixo -señalabadiversas porciones para mis alimentos y vestir y demás sus hermanos, por ser el único que ha podido adquirir bienes y caudal con su industria y trabaxo de escultor» (AHPM, prot. 3961, f. 15 r/v 2a num.). Añadía que había otorgado testamento para dejar clara esta circunstancia. El cuerpo de bienes de Nicolás Salzillo fue evaluado en 31.548 reales de vellón, las bajas se estimaron en 24.923 -que es lo que se adjudicó a Francisco- y el resto -6.625- correspondió a Isabel, que, repartidos entre sus seis descendientes solteros, les tocó a cada uno 1.104 reales y 5 maravedíes, con un sobrante de 4. Lo que heredó Francisco Salzillo fue la casa familiar en la parroquia de Santa Catalina donde todos vivían y estaba el taller, los útiles de trabajo, algunos cuadros y enseres domésticos (Herrero (coord.), 2006: 186-195). Debió ser un momento de convivencia difícil. El taller iba bien, pero no disponían de liquidez y todavía quedaba por afrontar la congrua de Patricio, cuyos bienes aportó Francisco y se suscribió la fundación el 13 de febrero de ese año de 1744 (Sánchez Moreno, 1945: 185; Herrero (coord.), 2006: 194-195).

A tan compleja situación, se sumó dos días después -15 de febrero de 1744- la muerte repentina de José Salzillo con 33 años y, en la jornada siguiente, fue enterrado en capuchinas (Sánchez Moreno, 1945: 43, 184; APSCM, LD 1708-1753, f. 55v). En los documentos suscritos en fechas anteriores no hay alusión a que estuviera enfermo. Debió ser un tremendo golpe emocional y desestabilizaría el ritmo de vida y trabajo, dada su dedicación al taller. No extraña que, así las cosas, el 27 de julio de 1744 Inés Salzillo, siendo doncella y concurriendo sola -lo que no deja de sorprender porque dependía económicamente de su hermano-, otorgase un poder general a José Fernández de Rueda, Diego Vázquez y Alejandro Rosique para que la defendiesen en todos los pleitos y negocios que tuviera (AHPM, prot. 3961, f. 78r/v; Sánchez Moreno, 1945: 185). Un censo que se efectuó en ese año revela que Francisco vivía en Santa Catalina con Patricio, las tres hermanas y su madre, así como un genovés llamado Jaime (Vela, 2007: 7). Sin embargo, el desajuste llegó al año siguiente con el óbito de la madre el 11 de octubre de 1745 (Sánchez Moreno, 1945: 43), cuando contaba 66 años. Como viuda de Nicolás Salzillo, Isabel Alcaraz tenía derechos sobre el taller, pero sin ella las cosas cambiaban. Por ende, Francisco contrajo matrimonio al poco tiempo en San Andrés con Juana Taibilla, hija de un platero y jurado del Concejo que había muerto en 1743. Fueron los padrinos de boda Inés Salzillo y José Taibilla, hermanos de los cónyuges. Así se reiteraba cuando Patricio Salzillo los veló en Santa Catalina el 13 de febrero de 1746: «En la ciudad de Murcia en treze días del mes de febrero de mill Settezienttos quarentta y seis años Yo Don Patricio Salcillo clérigo Presbíttero 
de licencia del Señor Don Juan Thomás Roxo, Y Alcaraz, Beneficiado y cura propio de la Iglesia Parroquial de Señora Santta Cathathalina [sic] Marttir de dicha ciudad, y comisario del Santto Oficio de la Inquisición velé según orden de nuesttra Santta Madre â Don Francisco Salcillo y a Doña Juana Taibilla feligreses de dicha Parroquial, los quales se desposaron en la de San Andrés de la expresada ciudad; fueron Padrinos Don Joseph Taibilla, y Doña Inés Salcillo. Y en fee de ello lo firmé» (APSNM, LM Santa Catalina 1739-1779, f. 45v; Sánchez Moreno, 1945: 43-44; Candel, 1983: 115).

Francisco Salzillo tendría un hogar propio y, en 1746, a su mujer le correspondieron 41.213 reales y 22 maravedíes de la legítima paterna y materna. Patricio, ya ordenado sacerdote, permaneció en la casa familiar, asistido por sus tres hermanas solteras. En septiembre de 1746 Francisco Salzillo dio poder a Francisco García Comendador II -futuro esposo de Inés Salzillo- y a otros procuradores para que los representasen a él y a su mujer en pleitos, causas y negocios, volviendo a hacerlo en 1766 (Herrero (coord.), 2006: 470-473, 720-723). Estos documentos reflejan que las familias Salzillo y García Comendador se trataron por motivos profesionales antes y después del matrimonio de Inés. De hecho, Francisco García Comendador II fue procurador, testigo y albaceas de Francisco Salzillo (Herrero (coord.), 2006, 100, 208, 224, 228). Era persona de su confianza antes de que emparentaran. En julio de 1748 nació Catalina de Ricci, primogénita del escultor. Recibió el nombre de la santa dominica canonizada poco antes, falleciendo al poco tiempo, como también Nicolás -nacido en 1750 y muerto al año siguiente- y otros descendientes (Candel, 1983: 114).

Inés Salzillo se casó en la parroquia de Santa Catalina de Murcia el 22 de diciembre de 1748 con el procurador Francisco García Comendador II, siendo velados el 10 de febrero de 1755 (APSNM, LM Santa Catalina 1739-1779, f. 65v; Sánchez Moreno, 1945: 184) [8], etapa esta última en que su hermano Francisco realizó algunos de los más destacados pasos para la Cofradía de Jesús de la ciudad [9]. Tenía 31 años y comenzaba para ella una nueva vida, alejada de la vertiente artística, junto a su esposo, algo menos que una década mayor que ella, pues él debió nacer hacia 1708. Los hermanos García Comendador quedaron huérfanos, primero de madre y después de padre en 1735, y debieron experimentar una situación de convivencia fraternal similar a los Salzillo. En el acta sacramental del matrimonio de Inés

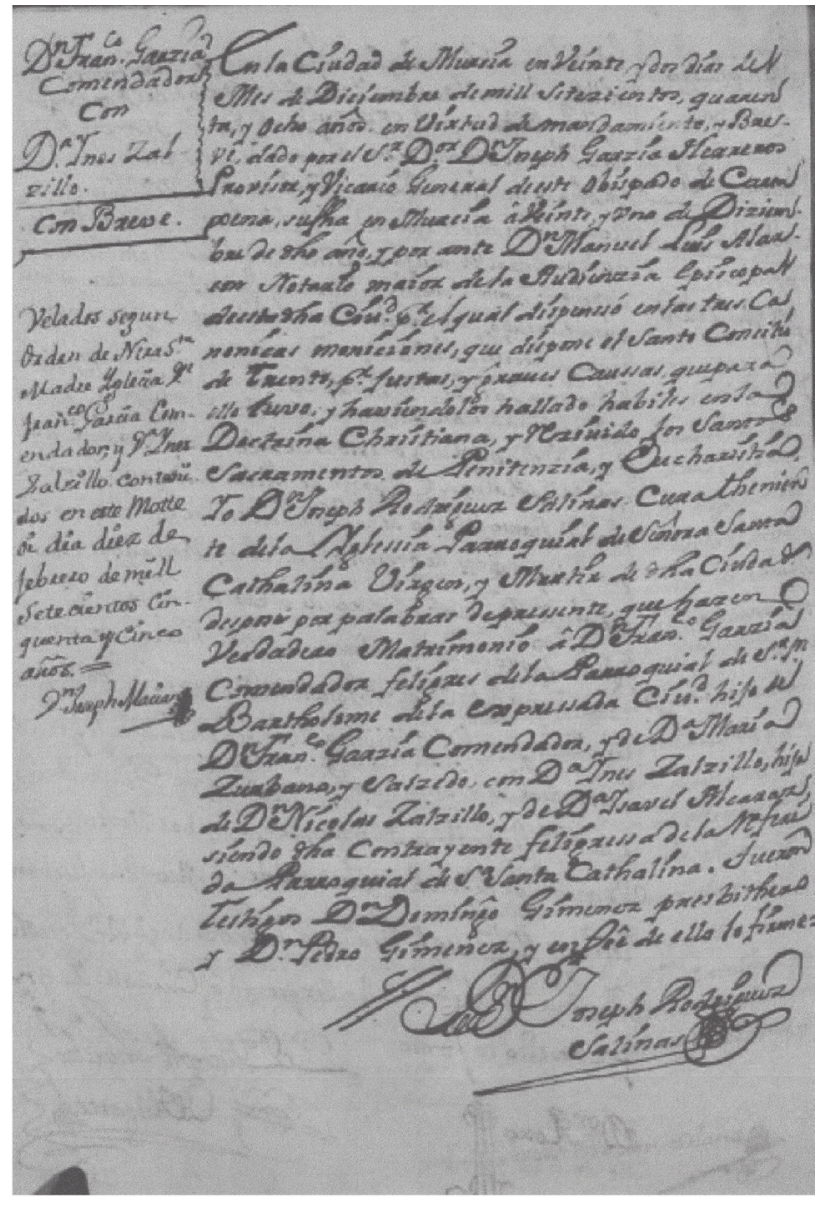

8. Acta de matrimonio y velaciones de Francisco García Comendador e Inés Salzillo en 1748 y 1755 en Santa Catalina de Murcia

consta la genealogía más próxima de ambos consortes. Él era hijo de María Zurbano Salcedo, natural de Madrid, y de Francisco García Comendador I, que lo era Sonseca en Toledo. Francisco García Comendador I fue también procurador de número en Murcia, confirmado en su título por Felipe $\checkmark$ el 21 de agosto de 1713, otorgando el mantenimiento de la propiedad a sus herederos ${ }^{3}$. Por el poder para testar que este último efectuó poco antes de morir, se conocen ciertos detalles familiares y sus vínculos con el obispo de Cartagena Tomás José de Montes -que lo fue desde 1724 a 1741-, dado que su hijo Juan García Comendador fue su cape\|lán (AHPM, prot. 2493, 3 febrero 1735, ff. 37r-38v; Candel, 1995). Posiblemente Juan García Comendador fuera promocionado por Belluga, el prelado anterior, a quien acompañó 


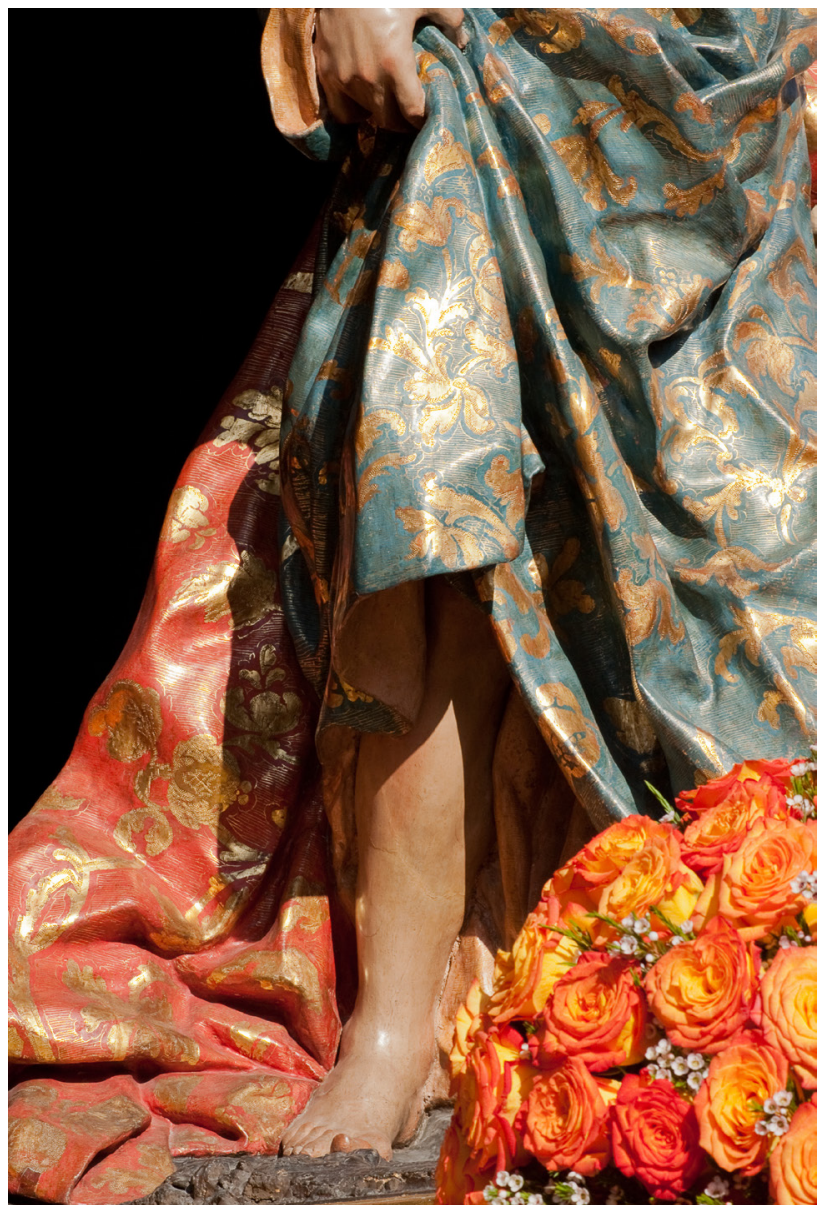

9. Francisco Salzillo, San Juan (detalle), 1755, Museo Salzillo de Murcia (Fotografía: M. Saura)

en alguna ocasión en sus visitas episcopales y, desde 1737 hasta su muerte en 1783, fue beneficiado y cura propio de Santa María, además de escotista y rector del Seminario de San Fulgencio de 1759 a 1763, inaugurándose la capilla de esta institución cuando él estaba al frente de la institución (Jiménez de Gregorio, 1949-1950: 163; Candel, 1995: 23)4. Francisco García Comendador I nombró herederos por iguales partes a Juan, a Francisco -que se casaría después con Inés Salzillo- y a Josefa -que permaneció soltera-, pues los otros hermanos renunciaron a sus legítimas antes de profesar, dado que fray Diego era agustino y Sor Clara capuchina, quien destacó por su humildad y obediencia según las crónicas de las religiosas. Francisco García Comendador II estuvo enfermo por entonces, estando todavía soltero, tal y como recalcaba en un testamento datado el 20 de mayo de 1735 (AHPM, prot. 2493, ff. 229r-230v). Designó entonces albaceas a Alonso de Mesa Fernández de Madrid, arcediano de Lorca, así como a los presbíteros Francisco Collados y Bernardo Sánchez, al escribano Francisco Espinosa de los Monteros y a familiares, nombrando por herederos a sus hermanos Juan y a Josefa García Comendador. Los nombres revelan los círculos sociales en los que se movía y las personas de su confianza en los años anteriores a sus esponsales con Inés Salzillo.

Francisco García Comendador II e Inés Salzillo estuvieron casados más de un cuarto de siglo, pues ella murió en 1775 y él en 1780. Tuvieron varios hijos. El mayor, Francisco García Comendador III -recibió los nombres de Francisco María del Pilar José Ignacio Vicente Nicolás, los últimos en recuerdo de su abuelo paterno, el escultor Nicolás Salzillo-, nació en 1752, siendo su compadre el regidor Joaquín María Prieto Mesa. Joaquín, clérigo formado en la Universidad de Orihuela, solicitó el examen de abogado en los años ochenta y murió en 1787 (AHN, Consejos, 12144, Exp. 58). La menor fue María Josefa, que recibió el nombre de su tía paterna y permaneció soltera. Los tres serían compañeros de juegos en la infancia de María Fulgencia Salzillo, nacida en enero de 1753 y única hija de Francisco que le sobrevivió. No mucho después Francisco Salzillo esculpía los ángeles niños de la Dolorosa, en una representación realista de la infancia que se inspiraría, sin duda, en su entorno infantil más próximo.

Se documentan escrituras diversas de Francisco García Comendador II como procurador. No le debió ir mal, pues en su último testamento declaraba no tener deudas, aunque deseaba que si alguna persona de buen crédito y bajo juramento dijera lo contrario que se le entregase hasta la cantidad de cuatro reales (AHPM, prot. 2348, 15 marzo 1780, ff. 166r-117v). Su profesión y este testimonio, junto a otros contenidos en diversos documentos, hacen pensar que Inés Salzillo vivió los más de veintiséis años de casada con una situación económica desahogada y una reputada consideración social, en un entorno próximo a sus hermanos, pues su parroquia continuó siendo Santa Catalina. La situación de su hijo Francisco García Comendador III, el único que se casó, no fue tan boyante, pese a que su profesión fue la de su progenitor. Él nada aportó al matrimonio, aunque luego heredó de sus padres y de sus tíos. Recibió la plaza de procurador que había concedido Felipe $\mathrm{V}$ a su abuelo, 
10. Acta de defunción de Inés Salzillo en 1775 en la parroquia de San Miguel de Murcia (Fotografía: M. Saura)

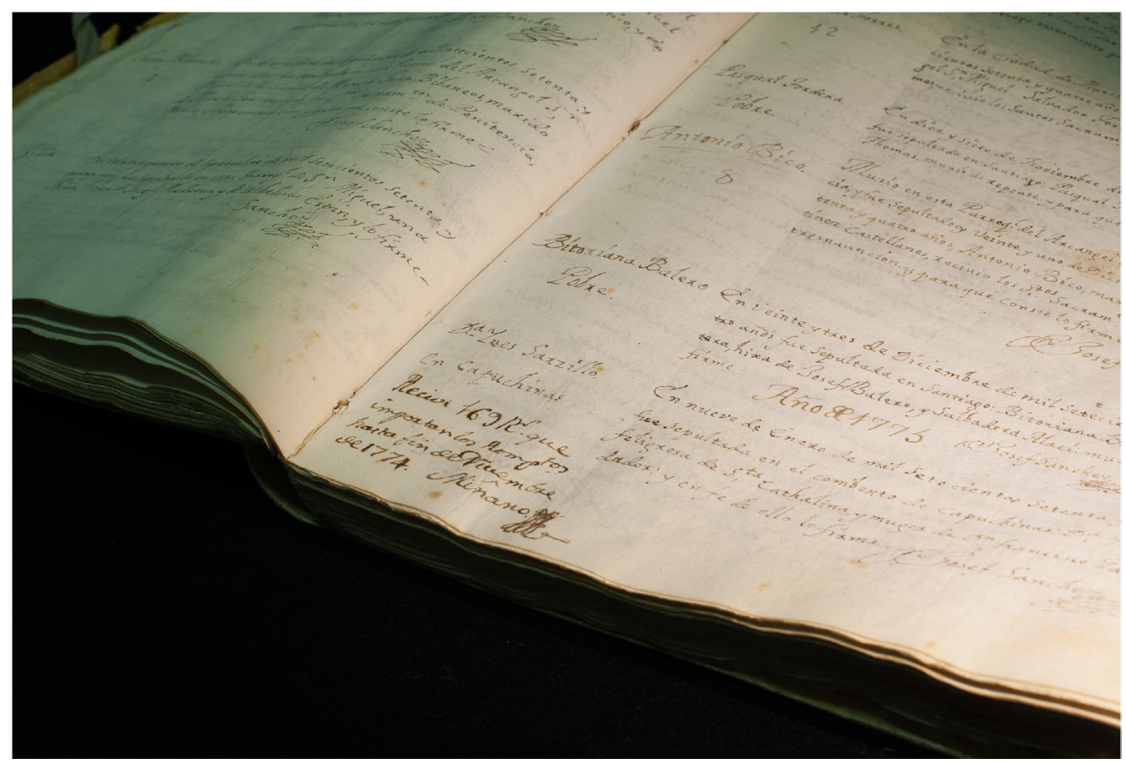

teniendo una parte de la misma su hermana María Josefa García Comendador, que era también usufructuaria de una casa en San Bartolomé, como consta su testamento fechado el 11 de diciembre de 1802, cuando estaba gravemente enfermo (AHPM, prot. 4226, ff. 771r-773v). Jesusa Jiménez de Cisneros, su esposa, llevó unos mil reales al matrimonio, después obtuvo bienes de su familia, en concreto alhajas, muebles y ropas que valían sobre 4.500 reales. Además, recibió de su hermano Manuel Jiménez de Cisneros 4.000 en dinero efectivo y de su tío Francisco Escribano una porción de tierra en la majada de las Pías Fundaciones del Cardenal Belluga. Francisco García Comendador III y Jesusa Jiménez de Cisneros, nacida en 1749 e hija del primer matrimonio del platero Andrés Jiménez de Cisneros con Gertrudis Escribano (Candel, 1999: 175), se casaron en San Bartolomé el 27 de noviembre de 1773, siendo velados el 5 de febrero de 1778 (APSCM, LM 1739-1779, f. 236r). Curiosamente Andrés Jiménez, que murió el 27 de abril de 1775, había trabajado piezas diseñadas por Francisco Salzillo y el escultor había sido su fiador (Sánchez Moreno, 1945: 80-81). Además el platero nombró curador de sus hijos a Francisco García Comendador II, marido de Inés, lo que de nuevo pone de manifiesto las redes sociales establecidas.

Inés Salzillo no llegó a conocer a sus nietos, pues murió en enero de 1775. Testó el día cinco y fue enterrada el ocho en capuchinas, como era costumbre en su familia por tradición materna, de ahí que figure la defunción tanto en la parroquia de Santa Catalina, como en la de San Miguel, de la que dependía el convento [10] (Sánchez Moreno, 1945: 184; APSNM, LD Santa Catalina 1749-1794, n. 7, f. 164v; APSMM, LD 1768-1796, f. 32r). Meses después, en concreto el 12 de septiembre de 1775, vino al mundo su nieto José, siendo su compadre su tío Joaquín García Comendador Salzillo, y falleció párvulo el 22 de marzo de 1780. Francisco García Comendador IV nació en 1778. Como sacerdote continuaría con la capellanía de capuchinas de su tío abuelo Patricio Salzillo y, en la Cofradía de Jesús de Murcia, como comisario de cruces y murió en 1813 (Candel, 1999: 319; Montojo, 2010: 91-92). Le seguirían Jesualdo García Comendador en 1781 y Mariano en 1782, quien fue militar de artillería destinado como capitán en el batallón de tiradores de Cádiz en la Guerra de la Independencia y como teniente coronel en Alcázar de San Juan, como revelan los testamentos que suscribió y el inventario de bienes fechado en 1844. Se casó con María Josefa Sedre Guillot.

Poco se sabe del período de Inés Salzillo como casada en Murcia, aunque ciertos documentos permiten aproximarse puntualmente a efemérides familiares, a la buena marcha del taller de escultura en el que había trabajado y al mantenimiento de los vínculos afectivos entre hermanos. En los años cincuenta, el Catastro del Marqués de la Ensenada aludía a los tres hogares de los Salzillo por aquel momento. 
Junto a Patricio Salzillo vivían dos hermanas, un estudiante menor de dieciocho y dos criadas (Candel, 1999: 317). Inés estaba junto a su esposo de 47 años, con dos hijos y una hija, declarando 1.100 reales. Francisco figuraba junto a su esposa, una hija, una criada y un aprendiz mayor de 18, a la sazón José López (Murcia, 1756: 1993: 86, 107, 292; Candel, 1999: 316-317). En el vecindario de finales de 1761, Francisco García Comendador II señaló lo mismo, salvo la diferencia de edad. El contexto de Francisco seguía igual, pero declaraba 3.000 reales en lugar de 2.540. En el poder para testar que se dieron mutuamente Francisco Salzillo y su mujer, Juana Vallejos, el 10 de abril de 1760 ambos declararon haber heredado de sus padres y que habían tenido «algunos gananciales». Además nombraron a Francisco García Comendador II, marido de Inés, como curador ad litem de su hija María Fulgencia (Herrero (coord.), 2006: 222). El 19 de diciembre de 1763 murió Juana Vallejos y al día siguiente fue enterrada, Francisco Salzillo practicó el 14 de marzo de 1764 el testamento de su esposa por poder, conjuntamente con su hermano Patricio y su cuñado José Vallejo -ambos presbíteros- (AHPM, prot. 3342, ff. 206r-208v). Se reiteraba lo sabido sobre los bienes de Francisco Salzillo. Es decir, que por herencia de sus padres le tocó la casa de detrás del convento de Santa Isabel, la del hogar familiar donde vivían sus cuñados, y que luego él compró «por sí mismo» otras dos de morada en Murcia sobre las que fundó patronato para que Patricio se ordenase sacerdote, con las reservas que se detallaban en la escritura de patronato. Ella, que nombró a su hija María Fulgencia por heredera, llevó los bienes que le correspondieron de sus padres. Finalmente reveló de nuevo que durante su matrimonio habían «tenido diferentes gananciales y comprado algunos vienes raízes», cosa que no sorprende porque los años de su matrimonio correspondieron a los de mayores demandas artísticas a su marido, amén de las numerosas transacciones que efectuó (Sánchez Moreno, 1945; Herrero (coord.), 2006).

El 18 de marzo de 1765 falleció Teresa Salzillo, siendo enterrada en Santa Catalina con hábito de capuchina. Había designado albaceas cinco días antes a sus dos hermanos varones y a sus dos únicas sobrinas les dejó abalorios femeninos. En concreto a María Josefa García Comendador, hija de Inés Salzillo, le dio un collar de perlas, unos pendientes y un abanico y, a Fulgencia Salzillo, descendiente de Francisco, el mejor abanico que tenía y unos vuelos de muselina
(AHPM, prot. 3344, ff. 150r-151v; Sánchez Moreno, 1945: 184; Peña y Belda, 2006: 22). Declaró de nuevo que no sabía firmar y lo hizo por ella Antonio Cánovas, que era testigo. La tierra en el Pago de la Alboleja, consistente en algo más de un tahúlla que heredó de su abuela Magdalena Gómez, se la dio a su hermana María durante toda su vida y de ella a Patricio, los tres que vivían juntos. De este pasaría a Inés y a sus hijos. Además, nombró herederos por iguales partes a sus hermanos Patricio, Teresa e Inés Salzillo, que no a Francisco. A finales de 1765 y estando gravemente enfermo, Francisco Salzillo otorgó testamento (Herrero (coord.), 2006: 228-259; Baquero, 1913: 480). Dejó sin vigor uno cerrado anterior, que ordenó en 1783 recoger a su hija y yerno. Nombró albaceas a Patricio Salzillo y a su cuñado José Vallejos, así como al marido de Inés, al que añadía en esta ocasión, pues Francisco García Comendador II no figuraba como tal en el anterior que suscribió en 1760. A los dos primeros los designó curadores ad bona y al otro ad litem de su hija, como ya había hecho antes, lo que revelaría que las relaciones entre todos continuaban siendo buenas. Recordaba que para que Patricio se ordenara fundó patrimonio sobre varias casas. Disponía que, en caso de morir Patricio, al ser sacerdote y no tener descendencia, la vivienda familiar que había pertenecido a Nicolás Salzillo, recayera sobre sus hermanas María e Inés, quienes la habrían de «tener, gozar y poseer en usufruto de por mitad» y pasaría de una a la otra, cuidándola y pagando censos. A la muerte de ambas recaería sobre María Josefa García Comendador, hija soltera de Inés, y de ella a María Fulgencia Salzillo, que lo era de Francisco (Herrero (coord.), 2006: 240-242; Baquero, 1913: 480). María Salzillo, su hermana, atendió a su hermano Francisco cuando quedó viudo, destacando el «expezial cariño y asistencias» que le debía.

El 19 de marzo de 1780 falleció Francisco García Comendador II siendo enterrado en capuchinas. Habían transcurrido cinco años de la muerte de su esposa, Inés Salzillo. El 15 de marzo de 1780 otorgó testamento. La gravedad de su enfermedad no le permitió firmar, aunque expresamente declaró que sabía (AHPM, prot. 2348, ff. 166r-117v). Nombró a sus tres hijos -Francisco, Joaquín y María Josefa García Comendador Salzillo- como herederos por partes iguales y designó por albaceas a su hermano Juan García Comendador -beneficiado de la catedral-, a su cuñado Patricio Salzillo y a su hijo Francisco García Comendador III. No 
se hizo partición formal y, como Joaquín era sacerdote y murió en 1787, sus bienes recayeron en Francisco y María Josefa García Comendador Salzillo, quien permaneció soltera. Un mes antes de la muerte del marido de Inés, Juan García Comendador redactó testamento y nombró herederos a sus hermanos Francisco y Josefa (AHPM, prot. 2450, 22 febrero 1780, ff. 17r-18v; Candel, 1995).

Después de que muriesen Inés Salzillo y su marido, documentos diversos constatan que los hermanos de ambos continuaron preocupándose por sus sobrinos, los García Comendador Salzillo. El 20 de febrero de 1783, al redactar Francisco Salzillo el último de sus testamentos -días antes de su fallecimiento-, reiteró el interés que había prestado a sus hermanos, manifestando lo siguiente: «lttem declaro que porque se mantengan con dezencia el referido mi hermano y hermanas les he dado a estas lo necesario y a aquel más de lo que ha merezido la asistencia y aiuda que me ha hecho en mi taller, lo que he llevado por apuntación. Quiero que de qualquiera que aparezca no se haga mérito alguno pues me doy por pagado y satisfecho y quedamos solventes yo y dicho mi hermano con solo esta declaración, y le suplico me encomiende Dios» (Herrero (coord.), 2006: 274). Nada declaró en relación al trabajo de Inés. Ciertamente que habían transcurrido muchos años desde que ella dejó el taller y había muerto, pero tampoco lo hizo en testamentos anteriores. Cabe pensar en la desigualdad de trato en lo que se refería a la retribución, según fuera varón o mujer, en tanto que Inés efectuaría una labor no remunerada, a cambio de su manutención y cuidado como mujer soltera, según los patrones de comportamiento vigentes. Por otro lado, Francisco Salzillo deseaba entonces que Patricio se quedara con las herramientas de la facultad y que dispusiera de ellas a su voluntad (Belda, 2001: 40). Añadía que Patricio había obtenido en 1781 por muerte del presbítero Pedro Pérez una capellanía colativa que le permitía su sustento -también fue capellán del Ayuntamiento- y, en consecuencia, habían quedado liberadas las fincas de la fundación realizadas en 1744 para su congrua. Francisco Salzillo no olvidó dejar algo para sus sobrinos varones, en concreto para Francisco García Comendador III un vestido de pana y para Joaquín otro de medio pelo. Aclaraba que su abuela Magdalena Gómez había transferido a sus cuatro hermanas una porción de tahúllas, pero la de Francisca, la religiosa capuchina, la había heredado él. Finalmente, encargó a su hija y a su yerno que atendiesen a María Salzillo, como él había he- cho durante toda su vida, manteniendo a todas las hermanas mientras fueron «doncellas». Cuando María Salzillo redactó su última voluntad el 3 de junio de 1784, nombró heredero a su hermano Patricio y, de fallecer este antes que ella, a su sobrina María Josefa García Comendador Salzillo. Lo designó también albaceas, junto a sus sobrinos Francisco y Joaquín García Comendador, hijos de Inés. A Josefa Jiménez -mujer de Francisco García Comendador III- y a Teresa García Comendador les dejó ropa blanca, cuyo reparto haría Patricio Salzillo (AHPM, prot. 2355, ff. 323r-325v; Sánchez Moreno, 1945: 186; Candel, 1999: 314-319). De las tahúllas que tenía heredadas de su abuela y de su hermana instituyó una pía memoria perpetua de misas en el altar de capuchinas por su alma y la de Teresa Salzillo. Deseaba que se cobrasen de los herederos de Francisco Salzillo los 300 reales que este había dejado para su entierro. Falleció el 3 de diciembre de 1786 siendo enterrada dos días después en el citado convento y, según Sánchez Moreno (1945: 186), ciertos autores consideraron que ella también colaboró en el taller familiar.

El 10 de marzo de 1800 Patricio Salzillo, estando grave enfermo, ordenó su testamento señalando albaceas y dando poder a sus sobrinos Francisco y María Josefa García Comendador, hijos de Inés Salzillo, a quienes nombró por herederos, pues Joaquín García Comendador había muerto. Patricio hacía constar que los bienes que estos habían heredado de sus padres los tenía en su casa, así como los que recibieron de sus tíos Juan y Josefa García Comendador, hermanos de su padre como únicos descendientes de los García Comendador Zurbano. Quería declararlo para que no saliesen perjudicados. Al primero le legó un cantarano que tenía en su habitación, a la esposa de su sobrino una urna con una imagen de Santa Bárbara y a su sobrina María Josefa otra con una escultura de la Concepción y un cuadro de la Dolorosa, dejando uno de la Magdalena a María Fulgencia Salzillo, hija de Francisco (AHPM, prot. 4421, ff. 221r-222v; Sánchez Moreno, 1945: 185-186; Candel, 1999: 314-319). Además, legó a Francisco, Jesualdo y Mariano, los tres hijos de Francisco García Comendador III y nietos de Inés Salzillo, la ropa y breviarios de su uso, distribuidos según considerara conveniente su padre. Patricio tenía deudas por importe de 2.700 reales según anotación que poseía, salvo 200 que no constaban y debía a José Ibáñez. El 13 de marzo de 1800 el último de los hermanos Salzillo fue sepultado en capuchinas, demostrando de nuevo el constante vínculo 
familiar con este convento, manifestado ya por su abuela materna y la mayor parte de los descendientes como lugar de sepultura, donde profesó su hermana Francisca de Paula Salzillo, donde fue capellán Patricio y luego seguiría Francisco García Comendador IV -nieto de Inés Salzillo, quien también tenía una cuñada que profesó en esta orden-y para donde Francisco Salzillo dispuso una manda testamentaria estipulando que, si era beatificada Sor Ángela Astorch -fundadora del cenobio murciano un siglo antes-, se facilitasen de sus bienes 1.500 reales para hacer la escultura (Baquero, 1913: 482; Herrero (coord.), 2006: 278). Además, Francisco Salzillo entregó en 1769 un Crucificado a la ermita de San Ginés con la condición que se dejara si era solicitado por las religiosas de esta orden para celebrar las tres horas de agonía el Viernes Santo, según ciertas condiciones (Herrero (coord.), 2006: 376-387). Finalmente, hay una alusión a que Catalina Antonia de Avilés, monja de esta comunidad, había curado a una hija pequeña de Francisco Salzillo, como también se decía que había sanado a otros niños enfermos ${ }^{5}$.

En suma, se ha tratado de hacer una historia de vida de Inés Salzillo a partir de documentos personales, que hablan de decisiones, sucesos y pertenencias. Contribuyen a construir la vertiente más emocional de su biografía. Aportan datos especialmente valiosos, al ser expuestos por la protagonista (Chárriez, 2012). Este recorrido vital femenino se ha acompañado del rastreo de información sobre Inés que ofrecen otras narrativas y que se han ido intercalando en el relato, de manera que no quedase aislada la figura de su entorno. Se trata de escrituras notariales firmadas por parientes y de datos contenidos en libros sacramentales. El tenor de los mismos sirve para completar aspectos sobre la cotidianeidad familiar, las vivencias colectivas, las redes sociales, los escenarios, los afectos y sufrimientos, las relaciones entre individuos -especialmente hermanos y descendientes-, los hechos y la dimensión de las personas como seres humanos.

De un taller en la familia a un taller familiar: Francisco Salzillo y la renovación y organización del trabajo en el obrador de escultura

En octubre de 1727 murió Nicolás Salzillo con 55 años de edad, dejando viuda de 48 años -28 de matrimonio- y siete hijos. No debió ser fácil para Isabel Alcaraz salir adelante cuando frisaba en el medio siglo, como sucedía, en general, con las viudas de esa edad y con tan numerosa prole (García González, 2016). No obstante, la situación de Isabel Alcaraz fue bien diferente económica y socialmente a la que tuvo su madre cuando murió su esposo. Nicolás Salzillo, oriundo de Santa María Capua Vetere donde sus antepasados se habían vinculado a oficios relacionados con la madera, llevaba casi tres décadas trabajando en Murcia y tenía clientes y reputación (Sánchez-Rojas, 1977-1978; di Liddo, 2008; Laurenza, 2017: 143-156). Discípulo de Aniello Perrone, con quien suscribió escritura de aprendizaje en Nápoles en octubre de 1689 por ocho años, poco después de que falleciese su maestro en 1696 se trasladó a Murcia, una ciudad de vida tranquila y con un clima no muy diferente al de su tierra de origen, donde ejercería sin que le pusieran trabas (Borrelli, 1993: 27-29). Baquero (1913: 210) afirmaba que se creía que, "como su mujer tenía bienes de fortuna, al cuidado de ellos se dedicó D. Nicolás más que á su profesión, pues eran bastantes para levantar las cargas del matrimonio». Sin embargo, aclaraba que vivió de su trabajo artístico, aunque la posición económica de su esposa constituyera una ayuda.

Por entonces, el número de escultores con vecindad en este núcleo urbano del sureste peninsular no era especialmente elevado y la influencia de maestros de los reinos de Granada y Valencia se hacía notar, constatándose la movilidad de artífices y el encargo y la circulación de piezas que llegaban y salían. En el tránsito de siglos tenían vecindad en la ciudad el estrasburgués Nicolás de Bussy, que venía precedido de su fama como escultor de Carlos II (Alonso, 2006). También estaban Andrés Martínez y Gabriel Pérez de Mena, formado con Pedro Roldán y perteneciente a una estirpe de imagineros, pues era hijo del escultor lorquino Antonio Pérez Crespo y de Sebastiana de Mena, descendiente de Alonso de Mena (Romero, 2013; Sánchez-Rojas y Peña, 1990: 489). También recibió algunos encargos Mateo Sánchez Eslava, que se trasladó a localidades de Andalucía Oriental, tomando vecindad en Guadix y muriendo en 1706. Mateo López Noguera puso a su hijo José López con Nicolás Salzillo y murió en 1716 (Sánchez-Rojas, 1977-1978: 268-269 y 1979-1980). En otras localidades próximas había otros artistas destacados. Por ejemplo en tierras del Noroeste murciano vivía el escultor de Burdeos Esteban de Gert, padre del tallista Juan de Gea -Juan de Gert Gea- y «uno de los insignes maestros que tiene este reyno", se decía en- 
tonces. En otros casos residieron temporalmente, así lo hizo Juan Perales, vecino de Orihuela.

Sin embargo, en 1707 Nicolás Salzillo afirmaba ser el único escultor de la ciudad en una solicitud al concejo (Peña y Belda, 2006: 19), como más de medio siglo antes había declarado Juan Sánchez Cordobés, nacido en Melilla y formado en Málaga y Granada, donde trabajó con Alonso de Mena (Gila, 2010). En plena Guerra de Sucesión, reclamó las exenciones que le correspondían como artista, en un lamento que dice mucho de la situación. Pedía que se le diese "por excusado de todo lo que mira a cargas conzexiles, por ser húnico en su arte de escultor, y haver tenido continuados aloxamientos, y hecho guardas en las puertas, no deviendo hazerlo por la razón referida y la de ser arte liberal» (AMM, AC, 4 julio 1707, f. 124r). Aires renovadores llegaron en la segunda década del Setecientos con Antonio Dupar, francés que trajo las influencias de Puget y de otros artistas, cuya vecindad se prologó hasta comienzos de los años treinta (Sánchez-Rojas, 1978-1979). Por entonces un escultor portugués trabajaba en los jerónimos de La Ñora. Es importante destacar que los tres aprendices que está documentado que suscribieron carta de soldada con Nicolás Salzillo en 1703, 1707 y 1710, al menos dos eran hijos de escultores, lo que demostraría el crédito que le concedían y lo que se consideraba que aportaría el maestro forastero con sus enseñanzas.

Francisco Salzillo, el mayor de los varones en su familia, contaba veinte años cuando perdió a su padre. No tuvo otra opción que asumir el control del taller y la responsabilidad de sacar adelante, con el dinero que generaba el quehacer escultórico, a su madre y a sus seis hermanos: una de 24 y el resto con 17, 15, 14, 10 y 5. Lo usual era alcanzar la maestría habiendo sobrepasado la veintena y Francisco debía estar concluyendo su formación y José a mitad de ella. En caso de fallecimiento del dueño del taller, la viuda podía mantener por un tiempo el negocio, con la ayuda del oficial más preparado, generalmente hijo, pariente o discípulo. Probablemente este fuera el caso de Isabel Alcaraz y Francisco Salzillo. Además, los hijos de maestros que seguían el oficio paterno solían gozar de algunas concesiones por corporativismo y porque se presuponía que conocían más el oficio, al haber discurrido su vida en un entorno de ejercicio profesional. Por otro lado y en caso de muerte del progenitor, el periodo establecido de aprendizaje cabía ami- norarlo. En el Reino de Murcia en el Barroco, no existieron ordenanzas que regulasen la práctica artística, como defendieron con ahínco en los años cuarenta escultores, tallistas, pintores y doradores, alegando que era una actividad liberal y no mecánica (Belda, 1992). El panorama hispánico fue diverso en esta cuestión de pertenencia o no de los artistas a gremios (Chocarro, 2001). Si bien, no estar incorporado en una de estas corporaciones no implicaba que no hubiera costumbres al respecto o exigencias, como la de limpieza de sangre y otras. En Murcia, no hubo exámenes de escultores y pintores en esa época, sino que, tras discurrir los años estipulados en la trayectoria formativa de aprendices y oficiales y estar y progresar con el número de maestros que se determinase -normalmente dos-, quien había sido el último «profesor» daba al oficial por hábil y suficiente para ejercer (Belda, 2001: 44). Para ser maestro de escultura había que tener un conocimiento completo de la disciplina y no efectuar una mera colaboración en una parte de la labor, como sucedió con Patricio e Inés Salzillo. Sin embargo, la presencia de estos últimos en el taller es importante porque manifiesta que existían otras formas de participación y de enseñanza artística más allá de las que reguladas.

No ostentar el título de maestro implicaba no tener licencia para abrir taller propio, ni poder recibir encargos. Ello no entrañaba que no se poseyeran habilidades, práctica y conocimientos. En este sentido, la nómina de féminas con vínculos en tareas artísticas fue un hecho generalizado. Madres, esposas e hijas, según las circunstancias, contribuirían de manera invisible como un eslabón esencial en la cadena de producción, bien en labores artísticas o ayudando en las gestiones para proveer y preparar ciertos materiales. Por demás, aprendices y oficiales solían vivir en el obrador, salvo que en las escrituras de servicio se acordase un régimen externo. Por tanto, las mujeres asumieron una carga mayor de trabajo en el hogar, para dar alimento, sustento y vida honesta y recogida a los discípulos de sus cónyuges, como se habían obligado a otorgárselo ellos por escrito o de palabra, junto a la enseñanza del oficio. De modo que, en la cotidianeidad, la colaboración de las mujeres fue esencial.

Para Francisco Salzillo, los primeros momentos al frente del obrador serían complicados, pues escasa fue la herencia y muchas las deudas, situación nada parecida a la de su padre cuando comenzó solo en la profesión, pero disponiendo de la sustancial dote de su esposa (Sánchez 
Moreno, 1945: 32, 34; Sánchez-Rojas, 1977-1978; Peña y Belda, 2006: 18-19; AHPM, prot. 3739, 18 julio 1700, ff. 371r-374v). Con Francisco fue al contrario: el taller existía, pero no había liquidez. Además de pagar a los acreedores, tuvo que buscar nuevos encargos, aumentar la producción y sacar adelante el trabajo con rigurosidad y consolidar un prestigio propio, en una etapa en que estaba, en palabras de Bado, falto de "práctica y experiencia» (Martínez Ripoll, 2006: 38). Como el mayor de los varones, llevaba la carga familiar, con todo lo que implicaba proporcionar manutención a ocho personas -amén de algún criado- y dote a sus cuatro hermanas, máxime cuando unas estaban en edad casadera y a otras les faltaba poco. Otra cosa es que luego dos de ellas permanecieran solteras y, en consecuencia, no necesitara reunir tantos bienes en poco tiempo, pero requirió otros para la que entró en religión y para que Patricio tuviera un medio de vida suficiente para ordenarse, como exigía la Iglesia. La documentación revela la compra de casas para conseguir una renta para su hermano y, después, tahúllas de moreras para la cría de gusanos de seda, práctica de larga tradición en Murcia (Olivares, 2005). Como su antecesor, tuvo otros negocios de tierras, censos y demás, cuyos ingresos aliviarían los gastos diarios. Mucho empeño debió poner y cuentas hacer para afrontar la economía doméstica.

Francisco Salzillo tenía claro su deber y los códigos de comportamiento correspondientes a las buenas costumbres. Los libros sobre el tema en esa época hablan de las obligaciones de cada uno de los miembros de la familia y de la forma de relacionarse de cónyuges, hermanos y padres con hijos. En caso de orfandad, se explicaba que los varones amarían a sus hermanas como si fueran sus progenitores, velarían por su honra y castidad y les facilitarían cuanto necesitasen (Morgado, 2002: 5-4, 30). De hecho, Rejón de Silva reparó en la conducta de Salzillo en este sentido, señalando que cuidó a sus hermanos menores "como padre hasta que tomaron estado" y que no fue a la corte para atenderlos (Martínez Cerezo, 2014: 63 y 2015: 59; García López, 2015: 119). En palabras de Bado «el tierno amor de su madre y hermanos eran las dulces cadenas que le tenían aprisionado y que jamás le permitieron perder de vista los estrechos límites de su patria» (Martínez Ripoll, 2006: 40). Tampoco renunció Francisco Salzillo a manifestarlo en su último testamento.

La organización del obrador a partir de 1727 correspondió a Francisco Salzillo y también la decisión del desem- peño de las actividades que cada persona efectuaría. Este fue uno de sus aciertos, aunque esta situación engendraría algún que otro inconveniente. Con él se pasó de tener un taller en la familia a conformar un taller familiar, que fue integrando paulatinamente a los hermanos, distribuyendo la labor a acometer en personas de su confianza, agilizando los tiempos, evitando demora en las entregas, rentabilizando el quehacer y obteniendo mayores rendimientos. Gestionar el obraje significaba constatar los problemas, evaluar la situación, tomar conciencia de sus necesidades y de la realidad económica, supervisar las actuaciones y considerar qué aspectos del entramado laboral había que reforzar y planificar, cumpliendo con los compromisos adquiridos. Francisco Salzillo fue consciente de la potencialidad que podía adquirir con cuatro hermanos trabajando y viviendo en el mismo hogar, pero realmente poco tiempo estuvieron todos colaborando a la vez. José fue su apoyo más temprano, pues se llevaban con él tres años y fue maestro escultor. Su muerte en 1744, cuando todavía era joven y quedaban casi cuarenta años de apertura del taller, truncó su porvenir. Cabe suponer que iniciaría su formación con su padre y la concluiría con Francisco y, quizá, con algún otro artífice. Su labor tendría lugar en los años treinta y comienzos de la década siguiente. Los dos pequeños, Inés y Patricio, participaron en algo tan esencial como era el acabado con el color, con los cambios experimentados respecto a los modos de su padre, pues recientes estudios en restauración han constatado las diferencias entre la técnica polícroma de Nicolás y Francisco Salzillo (Fernández, 2017: 649). Primero comenzaría Inés. Probablemente ya en los cuarenta, se integraría Patricio, que llegó y salió el último, incluso restauró imágenes con posterioridad (Sánchez Moreno, 1945: 185186; Candel, 1999: 318). Como sacerdote, orientaría a su hermano en ciertas cuestiones de licitud teológica, dado que Francisco fue censor del Santo Oficio. Baquero (1913: 219, 265) consideraba que se incorporó definitivamente cuando Inés se casó en 1748 y que llenó el importante hueco que ella dejó en la tarea de dorar, destacando en lo relativo a la colocación de los ojos de cristal. Sin duda tras el matrimonio de Inés, Patricio asumiría más trabajo, pero su participación es posible que llegase antes. La reestructuración del taller se debió producir tras la muerte de José, coincidente con la ordenación de subdiácono de Patricio y, en torno a dos años después, de sacerdote. Baquero (1913: 265) afirmaba 
que este último estudió en la Compañía de Jesús, y en el Seminario de San Fulgencio. Hasta el episcopado de Rubín de Celis, en el seminario se dieron clases de Derecho Canónico y los estudiantes, por disposición anterior del obispo Belluga, podían decidir cursar otras materias en cualquiera de los conventos de la ciudad (García y Azorín, 2015). De ahí el comentario de Baquero. Antes del óbito de José Salzillo, Patricio estaría estudiando para ordenarse y apenas tendría tiempo para el taller (Belda, 2001: 49). Después, no le impusieron grandes obligaciones pastorales, por lo que su disponibilidad sería mayor. Fue el único sacerdote que ejerció trabajos relacionados con la escultura en ese siglo en Murcia, según datos hasta ahora conocidos, bien que en sus aspectos pictóricos, pues no era especialmente apropiado para un sacerdote desempeñar una labor que requiriese tanto esfuerzo físico. En cambio, sí hubo varios pintores (Candel, 1999).

Francisco Salzillo consolidó su notoriedad por entonces y apenas tenía rival en las imágenes de devoción (Sánchez Moreno, 145: 183; Belda, 2001: 39). A finales de los treinta ya se hablaba del "célebre escultor de Murcia», caso de una obra que llegó a la parroquia de Orán, y del «escultor del primer crédito de estos reinos», en Lorca (Gómez Ortín, 2007: 34; Belda, 2001: 39). Conocía la teoría y práctica de su profesión. Sabía que había que dominar todo el proceso y, de hecho, él figuraba como pintor y escultor en algunos documentos (Belda, 1998). Por demás, un buen acabado era esencial. Desde el siglo XVIII hay referencias al ingente número de obras realizadas por Francisco, que no habría podido efectuar si no hubiera tenido un grupo de eficientes colaboradores junto a él. Dibujaba y modelaba bien -y los modelos fueron esenciales en su taller-, sabía dar forma y expresión, cuidaba la encarnación y el color de las prendas que correspondían a cada figura, imitando el tipo de tela que se determinaba o exigiera -tisú, restaño, encaje u otros- y dominaba la técnica del estofado y otras requeridas en la policromía. Enseñó a sus hermanos, con quienes disfrutaría de una comunicación fluida, beneficiándose de la ayuda femenina. En esos años y los siguientes no faltó jornal a tallistas y estatuarios en diferentes fases de formación y con la piedra como material diario de trabajo, en el importante obrador que dirigía Jaime Bort -arquitecto, cantero y escultor- para construir la fachada principal de la Catedral de Murcia y en otras obras de la escultura monumental. Si bien, ni Francisco, ni José Salzillo figuran en las cuentas del imafronte catedralicio (Hernández, 1990; Peña, 2016).

El punto de inflexión en el taller se produjo en 1744 y 1745, tras la muerte de José Salzillo y de su madre, Isabel Alcaraz. Poco después, Francisco Salzillo contrajo matrimonio, con la consiguiente obligación de sostenimiento de dos hogares. Estaba próximo a los 40 años y, sin duda, le preocuparía tener un sucesor. Luego llegarían los esponsales de Inés. No extraña la previsión de la madre de los Salzillo, al procurar dejar clara la situación patrimonial, si ella fallecía. Afirmaba esta que Francisco lo acometió todo «por si solo con su trabajo personal» y la industria de su arte. Ni Inés, ni Patricio poseían los requisitos exigidos legalmente para desempeñar de manera independiente la profesión, pero sí tenían un quehacer bien definido en la secuencia de actuaciones establecida para realizar unas obras que llegasen al devoto. Con frecuencia esta labor de pintar la escultura recayó en buenos pintores, aunque la casuística es variada en el Barroco hispánico (Belda 1998; Buchón, 2012), y cada vez más se van sumando más nombres de mujeres a ella. Por otro lado, las imágenes de vestir gozaban de un profundo arraigo en la religiosidad popular (Cea, 1992). Algunas de las piezas más logradas de Francisco Salzillo lo son y se asemejan más a lo real, como a él le gustaba. En general, una mujer sabía más de telas, colores, hechuras, bordados y prendas, aunque el escultor no pudo permanecer ajeno y daría las sugerencias precisas (Pérez Sánchez, 2007: 7475). Se asesoraría con los profesionales de la costura, pero también atendiendo a los consejos de Inés, que aportaría intuición y sensibilidad femeninas. Basta repasar las cuentas de la Dolorosa de la Cofradía de Jesús y constatar la necesidad de contar con entendidos en la materia. Por entonces Inés no estaba en el taller, pero permanecían sus otras hermanas solteras y antes Francisco Salzillo había tenido otros encargos de imágenes de devanadera. Si la imagen mariana costó 675 reales en la parte lignaria, cerca de 6.000 se requirieron para vestirla (Baquero, 1913: 467-471), reflejando tonalidades y telas muy del gusto del Rococó (Pérez Sánchez, 2007: 74-75). Se necesitaba estar en contacto con mercaderes, sastres, bordadores, cordoneros y otros oficios, además de con plateros. Tenía que estar pendiente de un acabado que repercutía sobre la apariencia de las esculturas de devoción, con sus ajuares de ordinario y festividad. Francisco Salzillo copió del natural, pero no le sería tan fácil 
encontrar rostros femeninos como referentes, por lo que debió buscarlos en su entorno cercano. Inés era la más joven de las mujeres que había en su hogar y le serviría de inspiración. Desde que fuera planteado el tema de los retratos a lo divino por Orozco hasta la actualidad se ha recorrido un largo camino, con toda la complejidad que el asunto presenta (Vincent-Cassy, 2016). Evidentemente que no se trataba de santos recientes, cuyo semblante era identificable, sino de otros lejanos cuyas rasgos faciales no se conocían y cuyo destino no era el ámbito doméstico, sino altares en templos.

Es complejo hablar de sello de identidad familiar. No obstante y pese a los cambios operados, hubo persistencias. Padre e hijo vivieron períodos distintos y mostraron gustos diferentes. Sobre la base de los repertorios que traía, Nicolás fue acomodándose a las demandas, exigencias y modas. Tuvo que hacerse un nombre en años difíciles, con un conflicto bélico de por medio. Francisco partió de un taller consolidado, pero redefinió el obrador y evolucionó a lo largo del tiempo. El segundo tercio del siglo XVIII fue un período singular y brillante para la escultura murciana por las circunstancias que concurrieron y por la personalidad y coincidencia de Jaime Bort y Francisco Salzillo. Nicolás Salzillo, «escultor de un mérito regular» según Bado, formó a sus hijos Francisco e inició a José en la totalidad de la enseñanza de la escultura y afianzó los conocimientos en dibujo y pintura de su primogénito, al disponer su aprendizaje junto a Manuel Sánchez, pintor y sacerdote. Bado decía que Nicolás fue «Director, Maestro y Bienhechor», así como ejemplo de virtud, por «la veracidad de sus palabras, la justificación de sus tratos, y la integridad de sus costumbres», pero él no llegó a conocerle (Martínez Ripoll, 2006: 32). En sus descendientes permanecería el poso cultural y pervivencia de las tradiciones de sus antepasados y ciertos hábitos instructivos en la enseñanza, técnica y trabajo del oficio, valiéndose de piedra y madera. Cabe pensar que primero Nicolás y después Francisco Salzillo tuvieron actitudes y vocación para enseñar y compartir conocimientos. De lo contrario sus compañeros de profesión no habrían puesto a sus hijos en el taller del artista napolitano. En cuanto a Francisco Salzillo, consideró, desde la experiencia de su pasado inmediato, las posibilidades que tenía y los desafíos ante el futuro. Al principio debió ser la premura por solucionar la situación profesional y familiar lo que le llevaría a instruir a José en el camino que marcó su padre y a especializar a sus hermanos pequeños en la parte pictórica de la escultura. Valoró la situación y pensó en la productividad y en qué era más adecuado para Patricio e Inés. Los adiestró en un quehacer concreto, como era la policromía, esencial para suscitar la piedad con las imágenes de devoción y conseguir la carga emocional que manifiestan. Él procuró los encargos, organizó y distribuyó las tareas, encadenó los quehaceres y estableció la rutina cotidiana. Pero también Inés aprendería de José y a su vez contribuiría a enseñar a Patricio. Luego llegaron los discípulos y la academia doméstica (Belda, 2012). Finalmente Francisco Salzillo murió siendo profesor y director de la Escuela de Dibujo de la Sociedad Económica. Bado hablaba de que era filósofo prudente, «afable, bondadoso y amante de la común instrucción» y de su casa como escuela pública a la se iba a aprender dibujo y «honrroso Museo» en que habitaron «la Naturaleza y el Arte» (Martínez Ripoll, 2006: 41, 43). En torno a medio siglo separan sus inicios enseñando en el taller barroco y el final en una institución ilustrada, con los profundos cambios y el paso de los valores naturalistas a la búsqueda de la belleza ideal (Belda, 2001: 32). Se constata la continuidad de unas prácticas, cuyos conocimientos y secretos pasaban de unos a otros, pero también de interacción de saberes y prácticas y de complicidad entre los miembros de la familia, que, en ciertos casos, en Murcia formaron compañías de trabajo entre hermanos en el ámbito artístico. Nicolás SalziIlo trajo sus modelos y perpetuó referentes de sus maestros y de otros artífices. Es posible que trabajase del natural, pero con Francisco esta práctica tomó carta de naturaleza, al igual, que la colaboración con tallistas y otros artífices, dotando a su obra de un sentido escenográfico y forjando unos arquetipos que arraigaron profundamente.

\section{Reflexiones finales}

Como continuadores del legado de Nicolás Salzillo -con sus pervivencias y rupturas- y a la sombra de su hijo Francisco estuvieron sus hermanos José, Patricio e Inés, efectuando cometidos de diversa significación artística, en una etapa de afianzamiento del taller y de consolidación temprana de su fama. De Inés Salzillo se sabe merced a los documentos existentes y a las escuetas pero convincentes alusiones que sobre su persona hicieron los biógrafos de Francisco, que 
se sumarían a leyendas y relatos apócrifos. No obstante, es complicado delimitar su praxis en obras concretas, que queda oscurecida en la labor cooperativa de grupo. El anonimato en los talleres relegó a ciertas personalidades, aunque la pieza artística sea reflejo del trabajo global de varios individuos con distintas capacidades y competencias bajo la dirección del maestro, con lo que entrañaba de jerarquización, respeto y obediencia. Por otro lado, repintes e intervenciones posteriores sobre las obras obstaculizan el acercamiento a su labor. La participación de Inés llegaría cuando, tras la orfandad paterna, Francisco Salzillo tomó conciencia de la situación y reestructuró el obrador. Paulatinamente fue involucrando a sus hermanos conforme tuvieron edad para trabajar y las circunstancias familiares y personales lo requirieron y permitieron, en una reflexión y planificación continuas, encomendándoles tareas concretas que constituían eslabones de una cadena de actuaciones. Definió las líneas estratégicas de futuro y estableció un modelo productivo, sacando provecho del potencial humano con el que contaba en su hogar en cada momento, en la reciprocidad de la confianza fraternal y las experiencias compartidas. Demostró previsión y capacidad para adaptarse.

Francisco Salzillo formó a Inés en el dibujo y en el color y, según se repetía en el siglo XIX, le sirvió de modelo para rostros de vírgenes y santas. Tras la muerte de su hermano José en 1744 y el matrimonio de Inés a finales de 1748 cuando contaba 31 años, Patricio Salzillo, ya como sacerdote, debió convertirse en un apoyo para Francisco en la tarea de acabar las piezas y, quizá, en recabar información sobre la iconografía y revisar otros aspectos relacionados con la observancia y rigor de los valores cristianos materializados en la escultura devocional. En los años siguientes, entrarían en el obrador sus discípulos José López y Roque López, pues faltaba mano de obra en un momento de muchas y destacadas demandas. En lo relativo a las prácticas artísticas, Inés colaboró, pero no obtuvo el título que la capacitaba como maestro, con todo lo que ello suponía. Normalmente tampoco a las mujeres se les solía permitir tenerlo, otra cosa es que tuvieran conocimientos y habilidades artísticas. Las fuentes revelan que no participó en todo el proceso de realización de la pieza escultórica. En este sentido, no pudo asumir encargos sola, aunque ostentara un papel destacado en el acabado de ciertas piezas, especialmente desde finales de los años treinta y en los cuarenta, con su buen hacer y esfuerzo diarios. Inés, como otras mujeres, no tuvo el mismo acceso a la cultura, ni posibilidades que los hombres, máxime en una profesión que engendraba mayores esfuerzos físicos y se consideraba de varones, al tiempo que ellas tenían ciertos vetos en la formación artística. De ahí que los útiles de trabajo de Inés fueran lápices, pinceles y herramientas para estofar, así como sus manos para modelar. Desempeñó una labor importante y no remunerada como tantas féminas que, adiestradas en el oficio de parientes cercanos, dedicaron su tiempo y cooperación al discurrir cotidiano en el taller, que era al mismo tiempo hogar, y reportaron bienestar a la familia. Su último cuarto de vida, Inés lo dedicó a su esposo e hijos. Gozó de una buena posición y se movió en círculos sociales entre las élites locales, pues su marido, Francisco García Comendador II, era procurador y su cuñado fue párroco de Santa María, rector del seminario y, anteriormente, capellán del obispo Montes. Murió con 57 años.

La familia siempre constituyó un vínculo esencial para Francisco Salzillo y sus hermanos. No obstante, la historia de sus relaciones -relaciones de dependencia recíproca- es más compleja que lo que muestran los candorosos tópicos presentes en las narraciones del siglo XVIII y difundidos oralmente, por la prensa y en los estudios decimonónicos sobre el escultor. Partían de hechos verídicos y hablaban del artista bondadoso que renunció a progresar fuera de Murcia por sus responsabilidades de parentesco. Cabe valorar el compromiso y entrañable cariño fraternal que Francisco Salzillo mostró a Inés y Patricio, que quedaron huérfanos con corta edad, así como el acierto en su incorporación al obrador y en su colaboración en la conclusión de las imágenes. Francisco Salzillo dirigió, supervisó y tuvo autoridad como maestro y patriarca de la familia, pero también intercambió ideas y experiencias laborales más allá de enseñante y discípulo. Ciertamente que todavía persisten muchos interrogantes, pero, merced al trabajo de José, Inés y Patricio Salzillo, el célebre escultor murciano pudo desarrollar su taller y afianzar su reputación artística.

Archivos citados: AGS (Archivo General de Simancas); AHN (Archivo Histórico Nacional); AHPM (Archivo Histórico Provincial de Murcia); AMM (Archivo Municipal de Murcia); APSMM (Archivo Parroquial de San Miguel de Murcia); APSNM (Archivo Parroquial de San Nicolás de Murcia); APSPM (Archivo Parroquial de San Pedro de Murcia). 


\section{Notas}

1 Trabajo realizado dentro de los proyectos Hispanofilia III (La influencia ibérica en su contexto político, siglos XVI-XX, Cód. HAR2014-52414-C2-1-P) e Hispanofilia IV (Los Mundos Ibéricos frente a las oportunidades de proyección exterior y a sus dinámicas interiores, Cód. HAR2017-82791-C2-1-P) del Ministerio de Economía y Competitividad y Columnaria I. Comprender las dinámicas de los Mundos Ibéricos, Código 19247/PI/14, de la Fundación Séneca. En las transcripciones se ha respetado la ortografía original.

2 Isabel Alcaraz nació en 1679, siendo bautizada el 3 de julio en la parroquia de San Pedro de Murcia (APSPM, LB 1676-1705, f. 28v). Su madre, Magdalena Gómez, volvió a casarse el 19 de diciembre de 1679, siendo velada el 1 de enero de 1680 (APSPM, LM 1679-1712, f. 123r/v). Tuvo varios hijos de su segundo matrimonio (Francisco nacido en 1686, José en 1690 y Josefa en 1698). Las buenas relaciones de Isabel Alcaraz con su padrastro se mantendrían al principio tras su matrimonio con Nicolás Salzillo en 1699. Tenía 19 años (APSPM, LM 1676-1712, ff. 123r, 124r; Sánchez Moreno, 1945: 32). Los problemas por la herencia arrancaron tras la muerte de Magdalena Gómez el 2 de agosto de 1717, siendo enterrada en capuchinas, y de Jerónimo Muzio el 6 de diciembre, descansando su cuerpo en la iglesia de San Francisco (APSPM, LD 1691-1743, ff. 119v-120r, 121r). En 1718 Francisco y José Muzio y Nicolás Salzillo suscribieron una escritura de compromiso para aceptar el dictamen de los abogados designados en relación a la herencia y evitar los gastos causados con tramitaciones judiciales (AHPM, prot. 3753, 6 abril 1718, ff. 63r-71v (2ª num.); Sánchez-Rojas, 1977-1978: 258-259; Peña y Belda, 2006: 18). Todavía en julio de 1751 Francisco Salzillo y sus hermanos -en el caso de Inés acudió su esposo previa licencia que ella le otorgó- dieron poder a procuradores para que se personasen en los autos formados sobre agravios en la partición de su abuela Magdalena Gómez (AHPM, prot. 2784, f. 216r/v; Herrero (coord.), 2006: 208-211). En 1759 José María Muzio, hermano uterino de Isabel Alcaraz, por vía testamentaria dispuso que, si fenecían los descendientes de sus sobrinos Muzio, que sus propiedades pasasen de mayor a menor a los de Isabel Alcaraz (Gómez Ortín, 2007: 27; AHPM, prot. 2672, 1759 ff. 39r-41).

3 AGS, EMR. Myp, leg. 400, f. 204. En línea en <http://archivoweb.carm.es/archivoGeneral/arg.muestra_detalle?idses=0\&pref_id=2283623> (fecha de consulta: 30-11-2017).

4 Agradezco a don José Luis García Hernández los datos y aclaraciones facilitadas, con su conocimiento profundo de los sacerdotes murcianos. Juan García Comendador escribió, junto a Juan López Bueno -que también fue rector de San Fulgencio-, Theatro de la Verdad y la Justicia (Murcia, 1750), como respuesta a las alegaciones del cabildo catedralicio tras el pleito comenzado en noviembre de 1739 entre los curas beneficiados de Santa María, sita en la catedral, contra la institución capitular por el derecho de la jurisdicción económica y curato de la parroquialidad en el citado templo. Del mismo modo, censuró y dio su aprobación a algunos libros piadosos.

5 AMM, Libro de memorias de Nuestras madres y hermanas difuntas, se enquadernó, año de 1787, siendo abadesa de este combento, la madre Sor María Joaquina Ximénez de Cisneros, ms., caja 49, n. 346, f. 6r/v.

\section{Bibliografía}

AGÜERA ROS, José Carlos (1994), Pintura y sociedad en el siglo XVII. Murcia, un centro del Barroco Español, Real Academia Alfonso X el Sabio, Murcia.

ALBARRÁN MARTÍN, Virginia (2008), «Se buscan escultores para el nuevo Palacio Real de Madrid», BSSA arte, n. ${ }^{\circ}$ LXXIV, pp. $203-218$.

ALONSO MORAL, Roberto (2006), «Nicolás de Bussy, escultor del rey. Su etapa en el Palacio de Aranjuez», en Nicolás de Bussy un escultor europeo en España. Tercer centenario de su muerte (1706-2006), Real Academia de Bellas Artes de Santa María de la Arrixaca, Murcia.

ÁLVAREZ, Begoña y RAMOS PALENCIA, Fernando (2018), «Human capital and earnings in eighteenth-century Castile», Explorations in Economic History, n. ${ }^{\circ}$ 67, pp. 105-133.

ARANDA BERNAL, Ana (2007), «Ser mujer y artista en España en la Edad Moderna», en Roldana, Junta de Andalucía, Sevilla, pp. 33-54.

BAQUERO ALMANSA, Andrés (1913), Catálogo de los Profesores de las Bellas Artes Murcianos: con una introducción histórica, Sucesores de Nogués, Murcia.

BELDA NAVARRO, Cristóbal (1992), La «ingenuidad» de las artes en la España del siglo XVIII, Discurso de recepción en la Real Academia Alfonso X el Sabio, Murcia.

- (1998), «Francisco Salzillo y la escultura pintada», en Francisco Salzillo. Imágenes de culto, cat. exp., Fundación Central Hispano, Madrid, pp. 37-52.

- (2001), Francisco Salzillo. La plenitud de la escultura, fotografías Carlos Moisés García, CajaMurcia, Murcia.

- (2012), «Los discípulos de Salzillo. Del taller a la academia doméstica», en BELDA NAVARRO, Cristóbal (ed.), Roque López, genio y talento de un escultor, CajaMurcia, Murcia, pp. 161-197.

BORRELLI, Gennaro (1993), «Aniello e Michele Perrone scultori napoletani», en DI LUSTRO, Agostino (dir.), Gli scultori Gaetano e Pietro Palatano tra Napoli e Cadice, Arte Tipográfica, Nápoles, pp. 9-31.

BOTÍAS, Antonio (2001), El Correo de Murcia. Un periódico del siglo XVIII, UCAM, Murcia.

BUCHÓN CUEVAS, Ana María (2012), «Pintar la escultura: apuntes sobre los doradores de los siglos XVII y XVIII en Valencia», Ars Longa, n. ${ }^{\circ} 21$, pp. 197-214. 
CANDEL CRESPO, Francisco (1983), «Aportación documental a la vida de Francisco Salzillo», en Francisco Salzillo y el Reino de Murcia en el siglo XVIII, cat. exp., Editora Regional, Murcia, pp. 113-126.

- (1995), Rectores del Seminario de San Fulgencio de Murcia 1700-1961, Muelas, Murcia.

- (1999), «Artistas fulgentinos», Scripta Fulgentina, n. ${ }^{\circ}$ 18, pp. 313-344.

CÁNOVAS DEL CASTILLO, Antonio (1887), Discursos leídos en la Real Academia de Bellas Artes de San Fernando en la recepción pública del Excmo. Sr. D. Antonio... el día 20 de Mayo de 1887, contestación del Marqués de Molins, A. Pérez Dubrull, Madrid.

CEA GUTIÉRREZ, Antonio (1992), Religiosidad popular. Imágenes vestideras, cat. exp., Zamora, Caja España.

CEÁN BERMúDEZ, Juan Agustín (1800), Diccionario Histórico de los más Ilustres Profesores de las Bellas Artes en España, v. VI, Viuda de Ibarra, Madrid.

CHÁRRIEZ CORDERO, Mayra (2012), «Historias de vida, una metodología de investigación cualitativa», Revista Griot, v. 5, n. 1, pp. 50-67.

CHOCARRO BUJANDA, Carlos (2001), La búsqueda de una identidad. La escultura entre el gremio y la Academia (1741-1833), Fundación Universitaria Española, Madrid.

COMAS, Javier (2016), «La restauración del retablo de Olivares descubre la firma de la hermana de La Roldana", ABC Sevilla, 30 diciembre.

CONDE DE LA VIÑAZA (1894), Adiciones al Diccionario Histórico de los más ilustres profesores de las Bellas Artes en España, v. III, Imprenta de los Huérfanos, Madrid.

DI LIDDO, Isabella (2008), La circolazione della scultura lignea barocca nel Mediterraneo, Napoli, la Publia e la Spagna. Una indagine comparata sul ruolo delle botteghe: Nicola Salzillo, De Luca Editori d 'Arte, Roma.

FERNÁNDEZ LABAÑA, José Antonio (2017), «San Francisco de Borja, una obra de Nicolás Salzillo», en CAÑESTRO DONOSO, Alejandro (coord.), Estudios de escultura en Europa, Instituto Juan Gil Albert, Alicante, pp. 639-674.

FUENTES Y PONTE, Javier (1900), Salzillo: su biografía, sus obras, sus lauros, Imprenta Mariana, Lérida.

GARCÍA ABELLÁN, Juan (1976), Organización de los gremios en la Murcia del siglo XVIII, Academia Alfonso X el Sabio, Murcia, 1976.

GARCÍA GONZÁLEZ, Francisco (2016), «Vejez, viudedad y soledad rural. Viudas, hogares y prácticas familiares en la España centro-meridional del siglo XVIII», Studia histórica. Historia moderna, v. 38, n. ${ }^{\circ}$ 2, pp. 287-324.

GARCÍA HERNÁNDEZ, José Luis y AZORÍN MARTíNEZ, Francisco José (2015), «El Colegio seminario de San Fulgencio (1592-1807)», en BELDA NAVARRO, Cristóbal (coord.), Maestros, escolares y saberes. Universidad de Murcia 1266-1915, cat. exp., Editum, Murcia, pp. 63-96.

GARCÍA LÓPEZ, David (2015), “'Era todo para todos’: la construcción biográfica de Francisco Salzillo durante el siglo XVIIl», Imafronte, n. ${ }^{\circ}$ 24, pp. 103-164.

GAZE, Delia (ed.) (2011), Concise Dictionary of Women Artists, Routledge, Londres.

GILA MEDINA, Lázaro (2010), «Juan Sánchez Cordobés: un desconocido escultor en la Granada de la primera mitad del siglo XVIl», Cuadernos de Arte de la Universidad de Granada, n. ${ }^{\circ} 41$, pp. 77-92.

GÓMEZ DE MAYA, Julián (2013), «Salzillo vindicado: su biografía artística por Chico de Guzmán», Murgetana, n. 128, pp. $71-86$.

GÓMEZ ESPINOSA, Teresa et al. (2004), «História e Evolução da Policromia Barroca», en Policromia: a escultura policromada religiosa dos séculos XVII e XVIII, Actas do Congreso Internacional, Instituto Português de Conservação e Restauro, Lisboa, pp. 37-53.

GÓMEZ ORTíN, Francisco Javier (2007), Contribución al catálogo y bibliografía de Salzillo, Instituto Teológico Franciscano, Murcia. HERNÁNDEZ ALBALADEJO, Elías (1990), La fachada de la Catedral de Murcia, Asamblea Regional, Murcia.

HERRERO PASCUAL, Ana (coord.) (2006), Francisco Salzillo. Vida y obra a través de sus documentos, Región de Murcia, Murcia, 2v.

IBÁÑEZ, José María, (1935), «El Colegio de 'La Anunciata'», Boletín de la Junta de Patronato del Museo Provincial de Bellas Artes de Murcia, n. ${ }^{\circ} \mathrm{XIII}, \mathrm{pp} .38-53$.

JIMÉNEZ BARRANCO, Antonio Luis (2000), María y Luciana de Cueto y Enríquez de Arana. Las Cuetas, Ayuntamiento de Montilla, Montilla. JIMÉNEZ DE GREGORIO, Fernando (1949-1950), «El Colegio-Seminario Conciliar de San Fulgencio (Aportación documental inédita al estudio de los precedentes de la Universidad Murciana)", Anales de la Universidad de Murcia, n. ${ }^{\circ}$ VIII, pp. 139-218.

LAURENZA, Giovanni (2017), Nicola Salzillo en Santa Maria Capua Vetere. El origen, UCAM, Murcia.

MARÍN TORRES, M. ${ }^{a}$ Teresa (1998), El Museo Salzillo, Real Academia Alfonso X el Sabio, Murcia. 
MARTíNEZ CEREZO, Antonio (2003-2004), «¿Qué fue de la Biografía de Salzillo escrita por Ramón Baquero López hacia 1840?», Imafronte, n. ${ }^{\circ} 17$, pp. $113-125$.

- (2014), «Vida de Salzillo para las 'Vidas' de Palomino», Nazarenos, n. ${ }^{14}$, pp. 62-69.

- (2015), «Vida de Salzillo. Transcripción del manuscrito de Diego Antonio Rejón de Silva (1754-96)», Nazarenos, n. ${ }^{\circ}$ 15, pp. 58-66.

MARTíNEZ RIPOLL, Antonio (2006), «Francisco Salzillo, un profeta en su tierra. Una biografía, con catálogo, por el matemático Luis Santiago Bado", en La Dolorosa y la Cofradía de Jesús. En el 250 aniversario de la Dolorosa, San Juan y la Verónica, Cofradía de Nuestro Padre Jesús Nazareno, Murcia, pp. 27-55.

MONTOJO MONTOJO, Vicente (2010), «Al son de bocinas y tambores. Francisco Salzillo Alcaraz y la Cofradía de Jesús (Murcia)», Murgetana, n. ${ }^{\circ} 123$, pp. $77-118$.

MORGADO GARCÍA, Arturo (2002), «Teología moral y pensamiento educativo en la España Moderna», Revista de Historia Moderna, Anales de la Universidad de Alicante, n. ${ }^{\circ}$ 20, pp. 1-51.

MUÑOZ LÓPEZ, María del Pilar (2009), «Mujeres españolas en las artes plásticas», Arte, Individuo y Sociedad, n. 21, pp. 77-88.

Murcia 1756: Según las Respuestas Generales del Catastro de Ensenada (1993), introducción Guy Lemeunier, Ministerio de Economía y Hacienda, Madrid.

OLIVARES GALVAN, Pedro (2005), Historia de la seda en Murcia, 2. ${ }^{a}$ edic., Editora Regional, Murcia.

PARDO CANALíS, Enrique (1983), Francisco Salzillo, 2. ${ }^{a}$ edic., Consejo Superior de Investigaciones Científicas, Madrid.

PEÑA VELASCO, Concepción (1983), «Francisco Salzillo, primer director de la Escuela Patriótica de Dibujo (1779-1783)», en Francisco

Salzillo y el Reino de Murcia en el siglo XVIII, cat. exp., Editora Regional, Murcia, pp. 153-167.

- (1985), Aspectos biográficos y literarios de Diego Antonio Rejón de Silva, Colegio Oficial de Aparejadores y Arquitectos Técnicos, Murcia. - (2016), «Taller, autoría y anonimato: Pedro Pérez, escultor barroco», Atrio. Revista de Historia del Arte, n. ${ }^{\circ} 22$, pp. 86-103.

PEÑA VELASCO, Concepción y BELDA NAVARRO, Cristóbal (2006), «Francisco Salzillo, artífice de su ventura», en HERRERO PASCUAL, Ana (coord.) (2006), Francisco Salzillo. Vida y obra a través de sus documentos, Región de Murcia, Murcia, pp. 18-43.

PEIRÓ MARTíN, Ignacio (2017), En los altares de la patria. La construcción de la cultura nacional española, Akal, Madrid.

PÉREZ SÁNCHEZ, Manuel (2007), «El patrimonio textil del Museo Salzillo», Datatèxtil, n. 16, pp. 67-75.

RAMALLO ASENSIO, Germán (2007), Francisco Salzillo, escultor, Arco, Madrid.

ROMERO TORRES, José Luis (2013), «Juan Pérez Crespo, escultor y padrino de La Roldana. Su trayectoria Lorca-Granada-Sevilla», Laboratorio de Arte, n. ${ }^{\circ} 25$, pp. 371-396.

RUIZ, Nacho (2017), «Inés, la luz de los Salzillos», La Verdad, 25 septiembre.

SÁNCHEZ LÓPEZ, Juan Antonio (2016), «Escultura Barroca en clave de género. Algunas reflexiones y propuestas de investigación», en FERNÁNDEZ PARADAS, Antonio Rafael (coord.), Escultura barroca española: nuevas lecturas desde los Siglos de Oro a la sociedad del conocimiento, ExLibric, Antequera, v. I, pp. 87-103.

SÁNCHEZ MORENO, José (1945), Vida y obra de Francisco Salzillo: una escuela de escultura en Murcia, Sucesores de Nogués, Murcia.

SÁNCHEZ-ROJAS FENOLL, M. ${ }^{a}$ Carmen (1977-1978), «El escultor Nicolás Salzillo», Anales de la Universidad de Murcia. Filosofía y Letras. XXXVI, n. ${ }^{\circ} 3-4$, pp. 255-296.

- (1978-1979), «La etapa murciana del escultor marsellés Antonio Dupar», Anales de la Universidad de Murcia. Filosofía y Letras, XXXVII, n. ${ }^{\circ} 1-2$, pp. 151-189.

- (1979-1980), «Escultura del siglo XVII en Murcia», Anales de la Universidad de Murcia. Filosofía y Letras. XXXVIII, n. ${ }^{\circ}$ 3, pp. $222-255$.

SÁNCHEZ-ROJAS FENOLL, M. ${ }^{a}$ Carmen y PEÑA VELASCO, Concepción (1990), "Los Mena y la escultura barroca murciana del siglo XVIl: Gabriel Pérez de Mena», en Simposio Nacional de Pedro de Mena y su época (Granada-Málaga, 1989), Junta de Andalucía, Málaga, pp. 481-492.

VELA URREA, José María (2007), Homenaje a la memoria del escultor murciano Francisco Salzillo y Alcaraz (1707-1783), Rosell, Murcia. VINCENT-CASSY, Cécile (2016), «Francisco de Zurbarán y el retrato sacro: Las santas vírgenes y mártires del maestro y su taller», Tiempos modernos, n. ${ }^{\circ} 33$, pp. 236-254. 